\title{
Non-coding RNAs (miRNAs and IncRNAs) and their roles in lymphogenesis in all types of lymphomas and lymphoid malignancies (Review)
}

\author{
GEORGIOS DRILLIS $^{1}$, MARIA GOULIELMAKI ${ }^{2}$, DEMETRIOS A. SPANDIDOS ${ }^{3}$, \\ SOFIA AGGELAKI ${ }^{4}$ and VASSILIOS ZOUMPOURLIS ${ }^{2}$
}

${ }^{1}$ 1st Internal Medicine Clinic, Medical School, Laiko University Hospital of Athens, 11527 Athens;

${ }^{2}$ Biomedical Applications Unit, Institute of Chemical Biology, National Hellenic Research Foundation (NHRF), 11635 Athens; ${ }^{3}$ Laboratory of Clinical Virology, and ${ }^{4}$ Oncology Unit, Medical School, University of Crete, 71003 Heraklion, Greece

Received December 16, 2020; Accepted February 26, 2021

DOI: 10.3892/ol.2021.12654

\begin{abstract}
Contemporary developments in molecular biology have been combined with discoveries on the analysis of the role of all non-coding RNAs (ncRNAs) in human diseases, particularly in cancer, by examining their roles in cells. Currently, included among these common types of cancer, are all the lymphomas and lymphoid malignancies, which represent a diverse group of neoplasms and malignant disorders. Initial data suggest that non-coding RNAs, particularly long ncRNAs (lncRNAs), play key roles in oncogenesis and that IncRNA-mediated biology is an important key pathway to cancer progression. Other non-coding RNAs, termed microRNAs (miRNAs or miRs), are very promising cancer molecular biomarkers. They can be detected in tissues, cell lines, biopsy material and all biological fluids, such as blood. With the number of well-characterized cancer-related lncRNAs and miRNAs increasing, the study of the roles of non-coding RNAs in cancer is bringing forth new hypotheses of the biology of cancerous cells. For the first time, to the best of our knowledge, the present review provides an up-to-date summary of the recent literature referring to all diagnosed ncRNAs that mediate the pathogenesis of all types of lymphomas and lymphoid malignancies.
\end{abstract}

\section{Contents}

1. Introduction

2. Literature search

Correspondence to: Dr Vassilios Zoumpourlis, Biomedical Applications Unit, Institute of Chemical Biology, National Hellenic Research Foundation (NHRF), 48 Vassileos Constantinou Avenue, 11635 Athens, Greece

E-mail:vzub@eie.gr

Key words: long non-coding RNAs, microRNAs, B-cell lymphoma, non-Hodgkin lymphoma, Hodgkin lymphoma, multiple myeloma, biomarkers
3. Non-coding RNAs in lymphomas

4. Anti-ncRNA therapeutic strategies in lymphoid disorders

5. Conclusions and future perspectives

\section{Introduction}

Lymphomas are a heterogeneous group of cancers; more specifically, they consist of a group of blood disorders derived from lymphocytes and are presented with multiple variations in clinical presentation, long-term prognosis and pathogenesis. They represent one of the most common types of cancer worldwide and affect numerous patients. According to the World Health Organization (WHO) classification report, there are approximately 100 different types of lymphoma. The two main categories of lymphomas are non-Hodgkin lymphoma (NHL) (consisting 9 out of 10 of all lymphoma cases) and Hodgkin lymphoma (HL) (consisting 1 out of 10 of all lymphoma cases) (1-3). Furthermore, non-Hodgkin lymphomas can be grouped into B- and T-cell NHLs (TNHLs), which account for approximately 90 and $10 \%$ of NHLs, respectively $(4,5)$. According to the WHO, two other categories are also considered as types of lymphoid tissue tumors: Multiple myeloma (MM) and immunoproliferative diseases (3).

Epidemiology. According to the WHO, there are the following lymphoma subtypes (WHO 2016): i) Mature B-cell neoplasms; ii) mature T-cell and natural killer (NK) cell neoplasms; iii) precursor lymphoid neoplasms; iv) HL; and v) immunodeficiency-associated lymphoproliferative disorders $(4,5)$.

B-cell NHLs (BCNHLs) are tumors of B-cells that exhibit a heterogeneity that is attributed to the fact that these tumors are derived from different stages of mature B-cell differentiation. The main subtypes of BCNHLs are the following: i) diffuse large B-cell lymphoma (DLBCL); ii) chronic lymphocytic leukemia (CLL); iii) follicular lymphoma (FL); iv) mantle cell lymphoma (MCL); v) Burkitt's lymphoma (BL); vi) marginal zone lymphoma (MZL); and vii) mucosa-associated lymphoid tissue (MALT) (6). The majority of BCNHLs, such as DLBCL and FL, have passed the germinal center (GC) reaction, indicating that their immunoglobulin (IG) genes have been 
hypermutated. Other subtypes, such as MCL and CLL, are derived from GC-inexperienced B-cells (7).

The most common subtypes of TNHLs and NK-cell NHLS (NK-NHLs) are the following: i) Cutaneous T-cell lymphomas (mycosis fungoides, Sezary syndrome and others); ii) adult T-cell leukemia/lymphoma; iii) angioimmunoblastic T-cell lymphoma; iv) extranodal NK/T-cell lymphoma; nasal type; vi) enteropathy-associated T-cell lymphoma; and vii) anaplastic large cell lymphoma (ALCL) (4).

Risk factors and diagnosis of lymphomas. The most common risk factors for HL are Epstein-Barr virus (EBV) infection and a family history of the disease (8). The most common risk factors for several types of NHLs include the following: i) Autoimmune diseases, such as Sjögren syndrome, celiac disease, rheumatoid arthritis and systemic lupus erythematosus; ii) HIV/AIDS infection; iii) human T-lymphotropic virus infection; iv) Helicobacter pylori infection; v) HHV-8 infection; vi) hepatitis $\mathrm{C}$ virus infection; vii) medical treatments (patients who have been previously treated for Hodgkin lymphoma, methotrexate and the tumor necrosis factor-a inhibitors); viii) genetic diseases; and ix) certain chemical agents (benzene and certain herbicides and insecticides; weed- and insect-killing substances) (9-15). Some environmental agents, such as red meat consumption and tobacco smoking may also play a role in increasing the risk of developing NHL $(11,12,16)$.

The diagnosis of lymphomas can be achieved due to the enlargement of lymph nodes, which can be determined by performing a lymph node biopsy (17). A lymph node biopsy commonly is followed by performing immunophenotyping, flow cytometry, fluorescence in situ hybridization testing, bone marrow aspiration and bone marrow biopsy (18). Imaging via computed tomography of the chest and upper-lower abdomen may then be performed to determine the possible expansion of the lymphoma throughout the human body (17).

Non-coding RNAs (ncRNAs). ncRNAs are RNAs that are not translated to proteins. Over the past ten years, a number of ncRNAs have been identified. Any of the three RNA polymerases (RNA Pol I, RNA Pol II or RNA Pol III) can perform the transcription of a ncRNA. The ncRNAs are divided into the following two main categories: Small ncRNAs, <200 bp in length and long ncRNAs (lncRNAs), >200 bp in length (19).

In these two categories, several individual categories of ncRNAs also exist. These include housekeeping ncRNAs [transfer RNAs (tRNAs) and some ribosomal RNAs (rRNAs)], which are essential for fundamental principles of cellular biology, small nuclear RNAs (snRNAs), and a number of recently observed RNAs which are associated with the transcription of genes into proteins (20).

MicroRNAs (miRNAs or miRs). To date, miRNAs are the less extensively studied ncRNAs for their roles in cancer. Over the past years, a number of targeted reviews have been published (21-23), which have described a complex basic mechanism through which miRNAs can lead to the silencing of target gene expression; through the formation of a silencing complex induced by RISC-induced RNA, which uses proteins from the Argonaute family (such as AGO2) for the splicing of target mRNAs or for the suspension of the translation of these mRNAs (21). The patterns of expression of miRNAs in different cancer types have been well-observed, and studies have highlighted numerous miRNAs, such as miR-10b, let-7, miR-101 and miR-15a-16 complex-1, which have oncogenic or tumor-suppressive functions $(22,23)$.

lncRNAs. Recent observations of new species of lncRNAs have led to the development of various possible candidates as lncRNAs. Although a number of RNAs have a length of $>200 \mathrm{bp}$, such as repeat sequence transcripts and pseudogenes (24), the term lncRNA (also referred to as lincRNAs, for long transgenic ncRNAs) is not used in the same manner in all cases.

A number of common features of lncRNAs have been indicated to confirm their biological identity, such as the following: i) Epigenetic regulation as in a transcripted gene; ii) transcription performed by RNA polymerase II; iii) poly-adenylation to the 3'-untranslated region (3'-UTR); iv) frequent splicing of multiple exons through specific molecular patterns; v) regulation by classic transcription factors; and vi) frequent tissue-specific expression (24) (Fig. 1).

ncRNAs in normal B-cell differentiation and T-cell development. B-cell differentiation in adult humans begins within the bone marrow $(\mathrm{BM})$ and is continued thereafter in the lymph nodes, tonsils and spleen (25). On the other hand, T-cells a derived from bone marrow hematopoietic stem cells (HSCs), whose progenitors migrate to and colonize the thymus (26).

The most common lncRNAs affecting normal B-cells are the following: i) MYB-AS1, SMAD1-AS1 and LEF1-AS1, located on $6 q 23.3,4 q 31.21$ and $4 q 25$, respectively, are involved in early B-cell development; ii) CRNDE, located on 16q12.2-involved in mitotic cell cycle related processes; and iii) RP11-132N15.3/lnc-BCL6-3, located on 3q27.3, and involved in the modulation of the GC reaction. However, data on the roles of lncRNAs in normal T-cells are limited (27-31).

miRNAs are also involved in lymphocyte development, as first described in 2004; it was demonstrated that miR-223, miR-181 and miR-142 were highly expressed in B-cells (32). miR-181 can also contribute to the regulation of the levels of CD69, BCL2 and TCR during T-cell development. In addition, miR-155 and miR-181 play key roles in the regulation of GC B-cell differentiation (33).

It is essential knowledge that all ncRNAs may play a vital role as predictive and prognostic biomarkers in the pathogenesis and progression of lymphomas and lymphoid malignancies in general. The main aim of the present review was to provide an up-to-date summary of available information on all the known miRNAs and lncRNAs that participate in the development of all lymphoid disorders, with a main focus on their connection to each lymphoma subtype. Furthermore, these molecular biomarkers may be used, in the near future, in the therapeutic management of the majority of lymphomas. Thus, the present review summarizes all published data to date on ncRNAs, in order to shed light on the future perspectives of lymphoma management.

\section{Literature search}

A literature search was performed, including studies published up to August, 2020, using the following databases: Medline (PubMed), Science Direct, Web of Science and Google Scholar. 


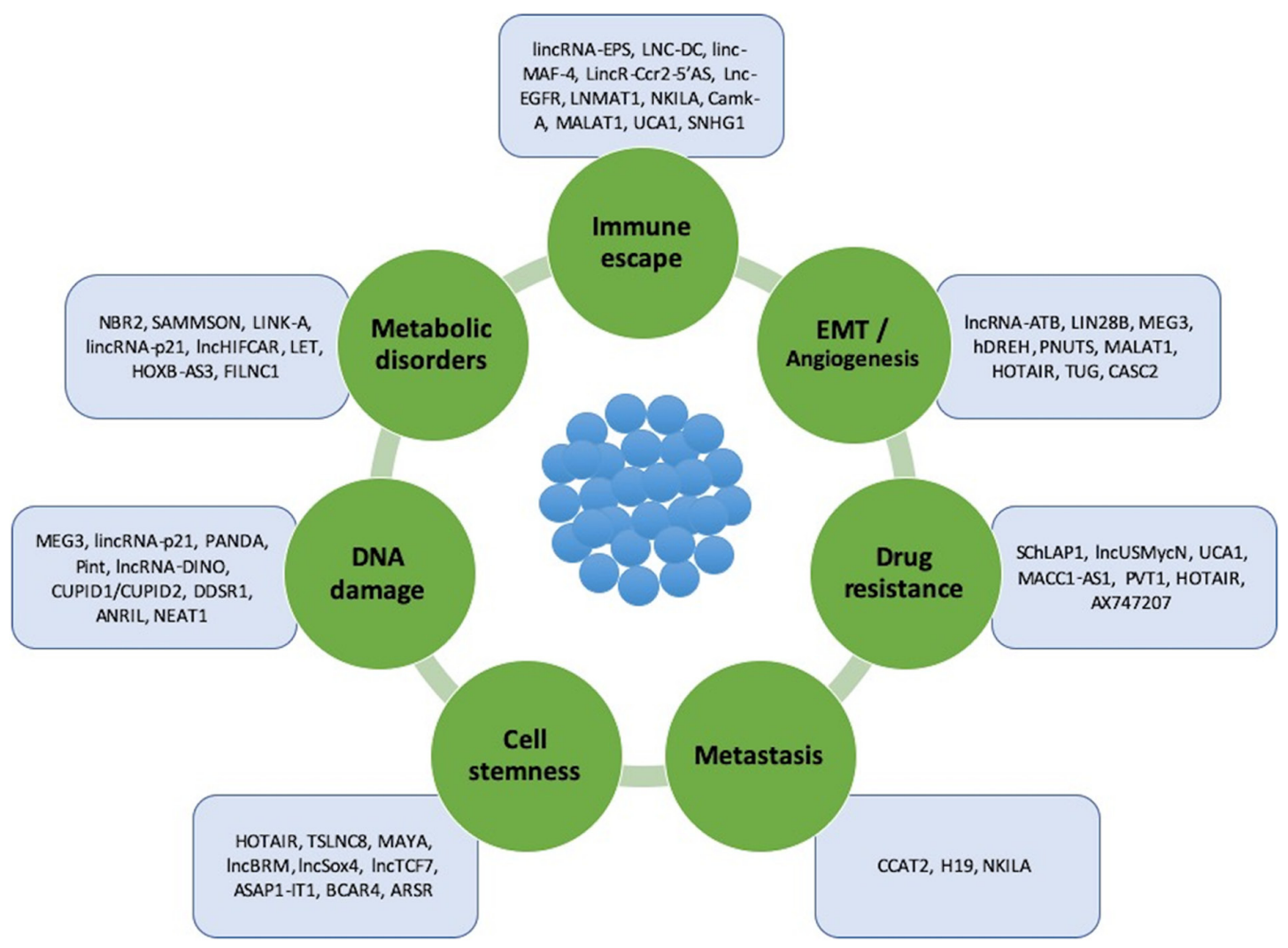

Figure 1. IncRNAs involved in oncogenesis, tumor progression and metastasis. These lncRNAs can be divided into 7 subtypes based on the process/property in which they are involved: Immune system escape, epithelial-mesenchymal transition, and angiogenesis, drug resistance, metastasis, cell stemness, DNA damage and metabolic disorders. lncRNAs, long non-coding RNAs.

Systematic reviews, uncontrolled prospective, retrospective and experimental studies were included for each specific subject (total no. of studies, $\mathrm{n}=235$ ). The following inclusion criteria were applied: Studies concerning ncRNAs, IncRNAs, miRNAs, cancer and lymphomas: HLs, and BCNHLs and TNHLs. All studies concerning the association of lncRNAs and miRNAs with NHLs and HLs were included.

\section{Non-coding RNAs in lymphomas}

Over the past years, a number of studies have referred to the significance of lncRNAs and miRNAs in the pathophysiology of lymphomas, particularly B-cell NHLs. There are different non-coding RNAs that play a role in each subtype of lymphoma, and these are referred to the sections and tables below (Figs. 2 and 3).

\section{a) BCNHLs}

$D L B C L$. Diffuse large B-cell lymphoma is the most common form of NHL among adults (34) and it occurs most often in older-aged individuals, with a median age of diagnosis approaching the seventh decade of a patient's life (35). There are 2 different molecular subtypes of DLBCL: GC B-cell like (GC-DLBCL) and activated B-cell like (ABC-DLBCL) $(36,37)$.

Subtypes of DLBCLs with a distinctive morphology or immunophenotype are the following: i) T-cell/histiocyte-rich large B-cell lymphoma; ii) $\mathrm{ALK}^{+}$large B-cell lymphoma; iii) plasmablastic lymphoma; iv) intravascular large B-cell lymphoma; and v) large B-cell lymphoma with IRF4 rearrangement $(38,39)$.

Subtypes of DLBCLs with distinctive clinical issues are the following: i) Primary mediastinal large B-cell lymphoma; ii) primary cutaneous DLBCL, leg type; iii) primary DLBCL of the central nervous system; iv) DLBCL associated with chronic inflammation; v) lymphomatoid granulomatosis; and vi) primary effusion lymphoma $(38,39)$.

Additionally, there are DLBCLs driven by viruses, such as the following: i) EBV-positive DLBCL, not otherwise specified; and ii) HHV8-positive DLBCL, NOS (Not otherwise specified). There are also DLBCLs driven by disorders related to DLBCL, such as: i) Helicobactor pylori-associated DLBCL; and ii) EBV-positive mucocutaneous ulcer $(40,41)$.

In order for a B-cell to be developed or to progress into a DLBCL type, changes in the following genes need to occur: BCL2 (42), BCL6 (42), MYC (36), EZH2 (43), MYD88 (42), CREBBP (44), CD79A and CD79B (44) and PAX5 (44). Therefore, the neoplastic cells in DLBCL exhibit a pathologically overactivation of the nuclear factor (NF)- $\mathrm{KB}$, phosphoinositide 3-kinase (PI3K)/AKT/mammalian target of rapamycin (mTOR), Janus kinase (JAK)/signal transducer and activator of transcription (STAT), mitogen-activated protein kinase (MAPK)/extracellular signal-regulated kinase (ERK), B-cell receptor and Toll-like receptor pathways (42).

Concerning miRNAs in DLBCLs, it has been shown than in ABC-type DLBCL lymphoma, there is a high expression of miR-21, miR-146a, miR155, miR-221 and miR-363, while in GCB-type DLBCL, there is a high expression of miR-421 and 

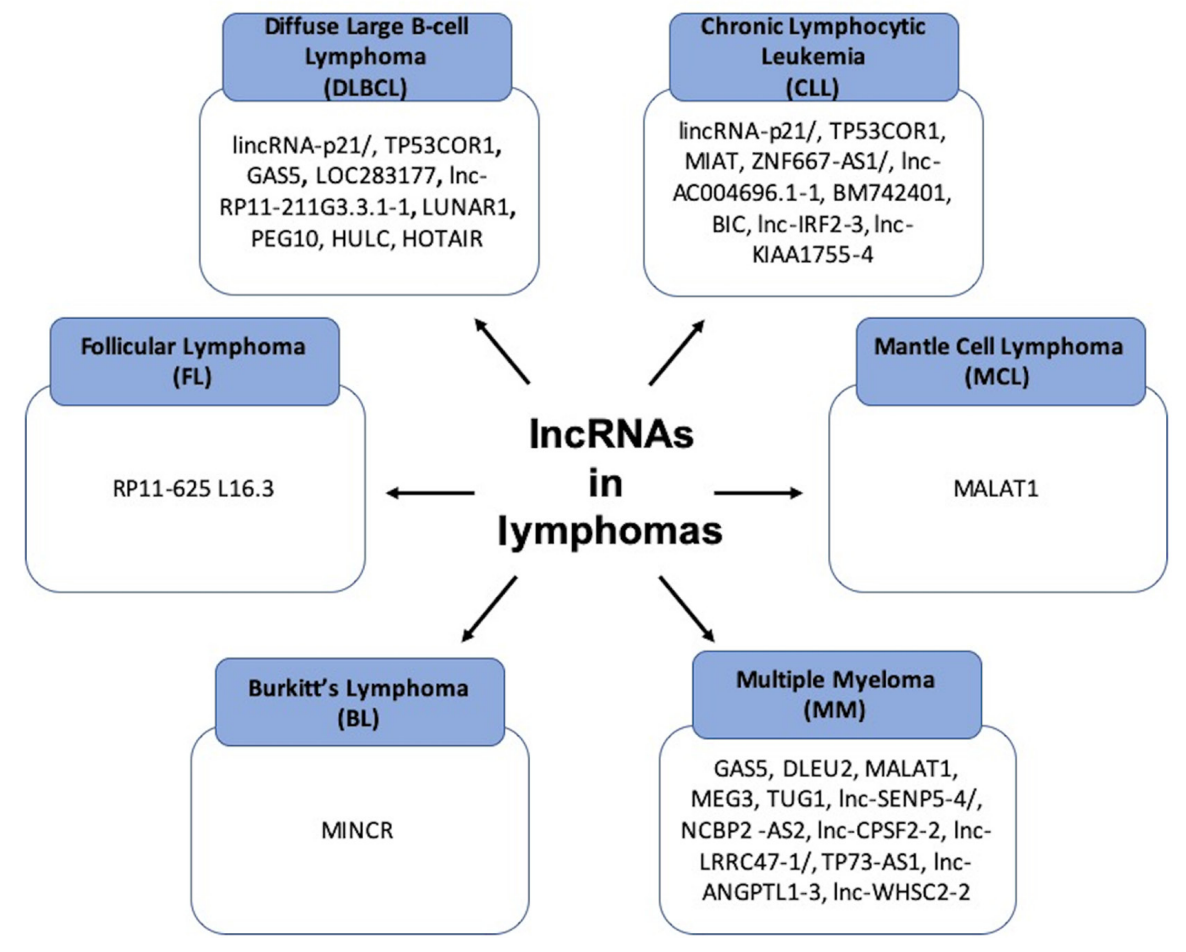

Figure 2. Summary of the major lncRNAs that are involved in different types of lymphomas. IncRNAs, long non-coding RNAs.
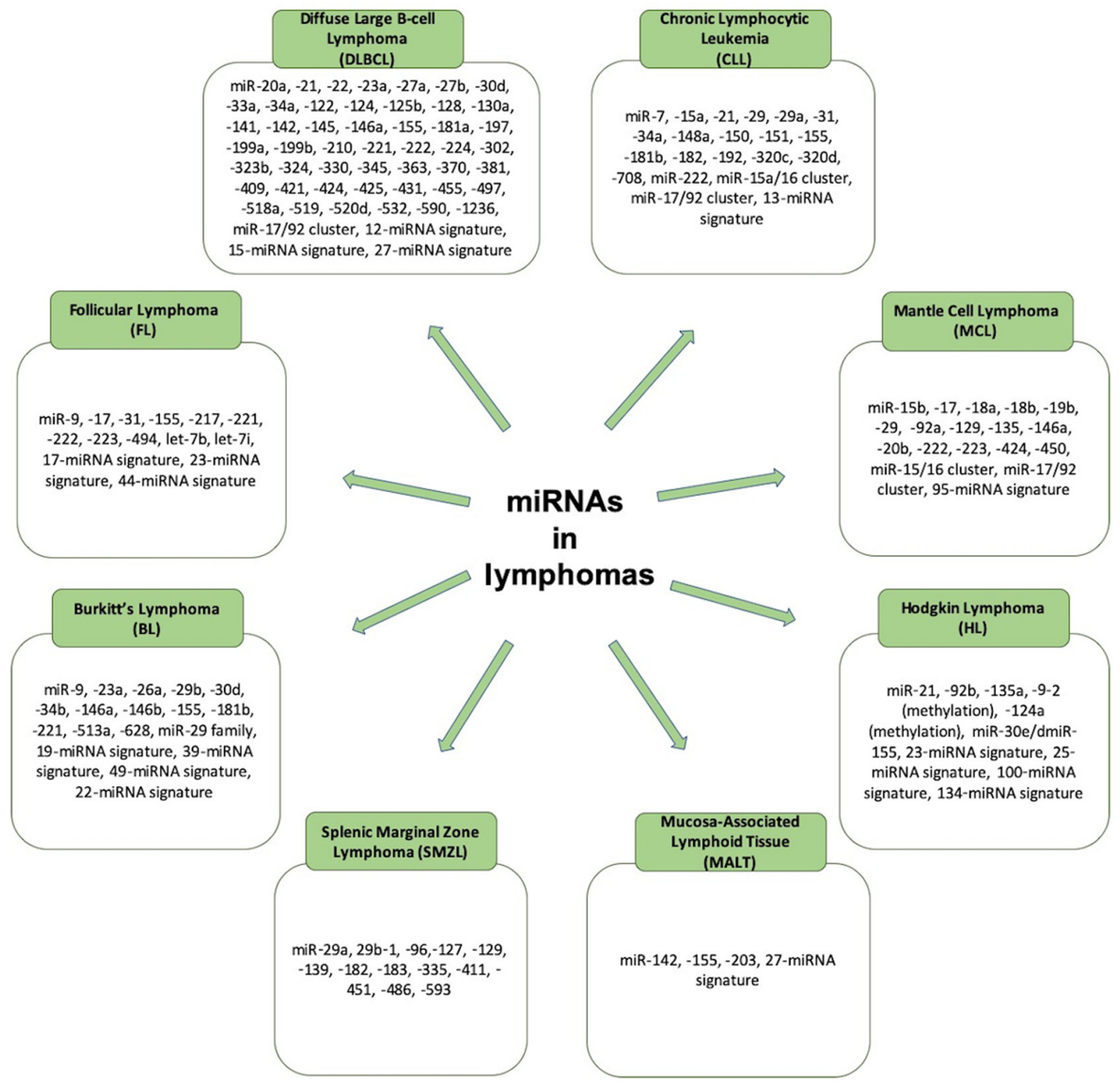

Figure 3. Summary of the miRNAs that are involved in different types of lymphomas. miRNAs, microRNAs. 
Table I. miRNAs and lncRNAs identified in patients with diffuse large B-cell lymphoma.

\begin{tabular}{|c|c|c|c|c|}
\hline $\operatorname{miRNA}(\mathrm{s}) / \operatorname{lncRNA}$ & $\begin{array}{l}\text { Genome } \\
\text { location } \\
\text { (if defined) }\end{array}$ & Role & $\begin{array}{c}\text { Molecular } \\
\text { mechanism/sample }\end{array}$ & (Refs.) \\
\hline miR-155 & & Diagnostic biomarker & Presence in serum & (51) \\
\hline miR-34a & & Diagnostic biomarker & Presence in serum & (52) \\
\hline miR-17/92 cluster & & $\begin{array}{l}\text { Cell survival, prognostic } \\
\text { biomarker }\end{array}$ & Subtyping & (53) \\
\hline miR-21, miR-23a, miR-27b, miR-34a & & $\begin{array}{l}\text { Poor overall survival, diagnostic } \\
\text { and prognostic biomarkers }\end{array}$ & Presence in serum & $(54-58)$ \\
\hline miR-20a, miR-30d, miR-22, miR-146a & & Prognostic biomarkers & Presence in tissues & (59) \\
\hline $\operatorname{miR}-21, \operatorname{miR}-210$ & & Diagnostic biomarkers & Presence in serum & $(60)$ \\
\hline $\begin{array}{l}\text { 12-miRNA signature, } 15 \text {-miRNA signature, } \\
\text { 27-miRNA signature }\end{array}$ & & Diagnostic biomarkers & Presence in tissue & $(61-64)$ \\
\hline $\begin{array}{l}\text { miR-155, miR-221, miR-222, miR-21, } \\
\text { miR-363, miR-518a, miR-181a, miR-590, } \\
\text { miR-421, miR-324 }\end{array}$ & & Diagnostic biomarkers & Presence in cell lines & $(65)$ \\
\hline $\begin{array}{l}\text { miR-124, miR-532, miR-122, miR-128, } \\
\text { miR-141, miR-145, miR-197, miR-345, } \\
\text { miR-424, miR-425 }\end{array}$ & & Diagnostic biomarkers & $\begin{array}{l}\text { Presence in plasma } \\
\text { and exosomes }\end{array}$ & $(66)$ \\
\hline miR-34a, miR-323b, miR-431 & & Diagnostic biomarkers & Presence in serum & (67) \\
\hline $\begin{array}{l}\text { miR-27a, miR-142, miR-199b, miR-222, } \\
\text { miR-302, miR-330, miR-425, miR-519 }\end{array}$ & & Predictive biomarkers & Presence in tissue & (46) \\
\hline $\begin{array}{l}\text { miR-224, miR-455, miR-1236, miR-33a, } \\
\text { miR-520d }\end{array}$ & & Predictive biomarkers & Presence in serum & $(68)$ \\
\hline $\begin{array}{l}\text { miR-125b, miR-130a, miR-199a, miR-497, } \\
\text { miR-370, miR-381, miR-409 }\end{array}$ & & Predictive biomarkers & $\begin{array}{l}\text { Presence in tissue, } \\
\text { blood and cell lines }\end{array}$ & $(69-71)$ \\
\hline lincRNA-p21/TP53COR1 & $\begin{array}{l}\text { 17p13.1 } \\
\text { (mouse) } \\
6 \mathrm{p} 21.2 \\
\text { (human) }\end{array}$ & Tumor-suppressor & $\begin{array}{l}\text { Link to cyclin D1, } \\
\text { CDK4 and p21 }\end{array}$ & $(72-76)$ \\
\hline GAS5 & 1q25.1 & Tumor-suppressor & $\begin{array}{l}\text { Regulation of mTOR } \\
\text { pathway }\end{array}$ & $(77-86)$ \\
\hline LOC283177 & $11 \mathrm{q} 25$ & Uncharacterized & Not described & (87) \\
\hline lnc-RP11-211G3.3.1-1 & $3 q 27.3$ & Uncharacterized & Not described & $(88)$ \\
\hline LUNAR1 & $15 \mathrm{q} 26.3$ & oncomiR progenitor & $\begin{array}{l}\text { NOTCH1 regulation. } \\
\text { Enhances IGF1R } \\
\text { mRNA expression }\end{array}$ & $(89,90)$ \\
\hline PEG10 & $7 q 21.3$ & oncomiR progenitor & Activated by c-MYC & $(91-93)$ \\
\hline HULC & $6 \mathrm{p} 24.3$ & oncomiR progenitor & Not described & $(94-97)$ \\
\hline HOTAIR & $12 q 13.13$ & oncomiR progenitor & $\begin{array}{l}\text { Regulation of the } \\
\mathrm{PI} 3 \mathrm{~K} / \mathrm{AKT} / \mathrm{NF}-\kappa \mathrm{B} \\
\text { pathway }\end{array}$ & $(98)$ \\
\hline
\end{tabular}

lncRNA, long non-coding RNA; miRNA/miR, microRNA.

the miR-17 92 cluster (45-50) (Table I). In serum samples of patients with DLBCL, increased levels of miR-21, miR-155 and miR-210 have been identified, along with increased levels of miR-124, miR-532-5p miR-15a, miR-16, miR-29c and miR-155. Decreased levels of miR-122, miR-128, miR-141, miR-145, miR-197, miR-345, miR-424 and miR-425 have been also found in the serum of patients with DLBCL. miR-27a, miR-142, miR-199b, miR-222, miR-302, miR-330, miR-425 and miR-519 seem to be associated with the overall survival of patients with DLBCL (50). In any case, miR-155, miR-34a, miRNA-21, miRNA-23a, miRNA-27b, miRNA-34a, 12-miRNA signature, 15-miRNA signature, 27-miRNA signature, miR-363, miR-518a, miR-181a, miR-590, miR-421 and miR-324-either in serum samples, or in tissue or cell line samples of patients with DLBCL, can be used as diagnostic biomarkers in patients with DLBCL (50-71) (Table I and Fig. 3). 
Table II. miRNAs and lncRNAs identified in patients with chronic lymphocytic leukemia.

\begin{tabular}{|c|c|c|c|c|}
\hline $\operatorname{miRNA}(\mathrm{s}) / \operatorname{lncRNA}$ & $\begin{array}{l}\text { Genome } \\
\text { location } \\
\text { (if defined) }\end{array}$ & Role/activation & $\begin{array}{c}\text { Molecular } \\
\text { mechanism/sample }\end{array}$ & (Refs.) \\
\hline $\begin{array}{l}\text { miR-15a/16 cluster, miR-7, miR-182, } \\
\text { miR-320c/d, miR-29, miR-192 }\end{array}$ & & Diagnostic biomarkers & $\begin{array}{l}\text { Presence in PBMCs and } \\
\text { cell lines }\end{array}$ & $(107,108,115,116)$ \\
\hline $\begin{array}{l}\operatorname{miR}-151, \text { miR-34a, miR-31, miR-155, } \\
\text { miR-150, miR-15a, miR-29a }\end{array}$ & & Diagnostic biomarkers & Presence in serum & $(113-114)$ \\
\hline $\begin{array}{l}\text { miR-181b, miR-21, miR-155, miR-708, } \\
\text { miR-17 92 cluster, 13-miRNA } \\
\text { signature, miR-150, miR-155 }\end{array}$ & & Prognostic biomarkers & $\begin{array}{l}\text { Presence in PBMCs, cell } \\
\text { lines, serum, blood cells }\end{array}$ & $(115,133-135)$ \\
\hline $\begin{array}{l}\text { miR-181b, miR-155, miR-21, } \\
\text { miR-148a, miR-222 }\end{array}$ & & Predictive biomarkers & $\begin{array}{l}\text { Presence in PBMCs and } \\
\text { cell lines }\end{array}$ & $(133-135)$ \\
\hline DLEU2 & $13 q 14.3$ & Tumor suppressor & $\mathrm{NF}-\kappa \mathrm{B}$ activation & $(117-120)$ \\
\hline NEAT1 & $11 \mathrm{q} 13.1$ & Tumor-suppressor & Induction by p53 & $(121,122)$ \\
\hline lincRNA-p21/TP53COR1 & $\begin{array}{l}17 \mathrm{p} 13.1 \\
\text { (mouse) } \\
6 \mathrm{p} 21.2 \\
\text { (human) }\end{array}$ & Tumor-suppressor & Induction by p53 & $(72-76)$ \\
\hline MIAT & $22 q 12.1$ & Oncogene & $\begin{array}{l}\text { Regulatory loop with } \\
\text { OCT4 }\end{array}$ & $(123-126)$ \\
\hline ZNF667-AS1/lnc-AC004696.1-1 & $19 q 13.43$ & Uncharacterized & Not described & $(127,128)$ \\
\hline BM742401 & $18 q 11.2$ & Tumor-suppressor & Not described & $(129,130)$ \\
\hline $\mathrm{BIC}$ & $21 q 21$ & oncomiR progenitor & $\begin{array}{l}\text { Host of miR-155-5p and } \\
\text { miR-155-3p }\end{array}$ & $(131,132)$ \\
\hline lnc-IRF2-3 & $4 q 35$ & Uncharacterized & Not described & $(128)$ \\
\hline lnc-KIAA1755-4 & $20 q 11.23$ & Uncharacterized & Not described & $(128)$ \\
\hline
\end{tabular}

lncRNA, long non-coding RNA; miRNA/miR, microRNA; PBMCs, peripheral blood mononuclear cells.

Concerning lncRNAs in patients with DLBCLs, the following have been observed (Table I): i) lincRNAp21/TP53COR1, located chromosome on 6p21.2 (human), acting as a tumor suppressor by linking to cyclin D1, CDK4 and p21 (72-76); ii) GAS5, located on chromosome 1q25.1, acting as a tumor suppressor by regulating the mTOR pathway (77-86); iii) LOC283177, located on chromosome 11q25, with an uncharacterized mode of action (87); iv) lnc-RP11-211G3.3.1-1, located on chromosome 3q27.3, with an uncharacterized mode of action (88); v) LUNAR1, located on chromosome 15q26.3, acting as an oncomiR progenitor by regulating NOTCH1 and enhancing insulin-like growth factor 1 receptor (IGF1R) mRNA expression $(89,90)$; vi) PEG10, located on chromosome $7 \mathrm{q} 21.3$, acting as an oncomiR progenitor, and being activated by c-MYC (91-93); vii) HULC, located on chromosome 6p24.3, acting as an oncomiR progenitor (94-97); viii) HOTAIR, located on chromosome $12 \mathrm{q} 13.13$, acting as an oncomiR progenitor, via the regulation the of the PI3K/AKT/NF- $\mathrm{B}$ pathway (98) (Fig. 2).

CLL. CLL is the most common form of leukemia affecting adults (99). In the case that along with CLL, there are enlarged lymph nodes, this clinical condition is referred to as small lymphocytic lymphoma (SLL). The groups of CLL/SLL monoclonal B-cells are the following: Low-count CLL/SLL with a number of monoclonal B-cells $<0.5 \times 10^{9}$ cells $/$ liter (i.e. $0.5 \times 10^{9} / 1$ ), and high-count CLL/SLL MBL with monoclonal B-cells $\geq 0.5 \times 10^{9} / 1$ but $<5 \times 10^{9} / 1$ (99). A patient is diagnosed as having CLL if the number of monoclonal B-cells are $>5 \times 10^{9} / 1(100,101)$. Classical CLL, according to the Matutes score (102), includes the expression of five different markers in the immunophenotype: These are CD5, CD23, FMC7, CD22 and immunoglobulin light chain (102-104).

Concerning miRNAs in CLL, miR-15a/16-1 acts as a tumor suppressor in patients with CLL and its expression is therefore found to be decreased $(105,106)$, while miR-7-5p, miR-182-5p and miR-320c/d are regulated by $\mathrm{p} 53$, and are increased in patients with CLL $(107,108)$. miR-181b expression is also low in patients with CLL (with a poor outcome) (109). miR-155 is overexpressed in patients with CLL and together with miR-21, lead to higher mortality levels in patients with CLL (110) (Table II and Fig. 3).

Additionally, patients with CLL are characterized by higher levels of miR-34a, miR-31, miR-155, miR-150, miR-15a and miR-29a; these can be used as diagnostic biomarkers (110-115). In particular, miR-192 is expressed in low levels in patients with CLL and can be thus used a diagnostic biomarker for CLL (116) (Table II). 
Table III. miRNAs and lncRNAs identified in patients with follicular lymphoma.

\begin{tabular}{|c|c|c|c|c|}
\hline $\operatorname{miRNA}(\mathrm{s}) / \operatorname{lncRNA}$ & $\begin{array}{c}\text { Genome } \\
\text { location } \\
\text { (if defined) }\end{array}$ & Role/activation & $\begin{array}{c}\text { Molecular } \\
\text { mechanism/sample }\end{array}$ & (Refs.) \\
\hline RP11-625 L16.3 & 12 & Uncharacterized & Not described & $(72)$ \\
\hline miR-9, miR-155, miR-31, miR-17 & & Diagnostic biomarkers & Presence in tissues & $(136,137)$ \\
\hline miR-217, miR-221, miR-222, miR-223, let-7i, let-7b & & Diagnostic biomarkers & Presence in tissues & $(138,140)$ \\
\hline 17-miRNA signature, 44-miRNA signature, miR-494 & & Diagnostic biomarkers & Presence in tissues & $(138,139)$ \\
\hline 23-miRNA signature & & Predictive biomarkers & Presence in tissues & (139) \\
\hline
\end{tabular}

lncRNA, long non-coding RNA; miRNA/miR, microRNA.

Concerning lncRNAs in patients with CLL, the following have been observed (Table II): i) DLEU2, located on chromosome $13 \mathrm{q} 14.3$, acting as tumor suppressor by activating the NF- $\mathrm{B}$ pathway (117-120); ii) NEAT1, located on chromosome 11q13.1, acting as a tumor suppressor via induction by p53 $(121,122)$; iii) lincRNA-p21/TP53COR1, located on chromosome p21.2 (human), acting as a tumor suppressor via induction by p53 (72-76); iv) MIAT, located on chromosome $22 \mathrm{q} 12.1$, acting as an oncogene by forming a regulatory loop with OCT4 (123-126); v) ZNF667-AS1/lnc-AC004696.1-1, located on chromosome $19 q 13.43$, with an uncharacterized mode of action $(127,128)$; vi) BM742401, located on chromosome 18q11.2, acting as a tumor suppressor, with an uncharacterized mode of action $(129,130)$; vii) BIC, located on chromosome 21q21, acting as an oncomiR progenitor by being a host of miR-155-5p and miR-155-3p (131,132); viii) lnc-IRF2-3, located on chromosome 4q35 with an uncharacterized mode of action (128); ix) lnc-KIAA1755-4, located on chromosome 20q11.23 with an uncharacterized mode of action (128) (Fig. 2).

Finally, in Table II, references are provided of all the other miRNAs used as predictive and prognostic biomarkers in clinical trials of patients with CLL (133-135).

FLs. FL is the second most common type of NHL, and the most common indolent NHL. It derives from the uncontrolled division of centrocytes and centroblasts of the follicles in the GCs of lymph nodes.

The genomic alterations that can be found in FL include the following: i) the $\mathrm{t}(14: 18)(\mathrm{q} 32: \mathrm{q} 21.3)$ translocation (the majority of the cases); ii) 1p36 deletions (second most common genomic alteration in FL) that lead to the loss of TNFAIP3; iii) mutations in PRDM1; and iv) the same mutations observed in in situ FL (ISFL), including KMT2D, CREEBP, BCL2 and $\mathrm{EZH} 2$, as well as other mutations (45).

According to the WHO criteria, there are differences, which can be observed under a microscope, which can be used to diagnose and categorize FL into the following 3 grades, with grade 3 comprising A and B subtypes (46): Grade 1, follicles with $<5$ centroblasts per high-power field (hpf); grade 2, follicles with 6 to 15 centroblasts per hpf; grade 3 , follicles with $>15$ centroblasts per hpf; grade $3 \mathrm{~A}$, grade 3 in which the follicles contain predominantly centrocytes; grade 3B, grade 3 in which the follicles consist almost entirely of centroblasts.
Low-grade FLs are grades 1 and 2, as well as grade 3A. Grade $3 \mathrm{~B}$ is regarded as a highly aggressive FL, which can be easily transformed into a higher grade (46). The transformation of FL into a more aggressive state or other type of aggressive lymphoma is associated with specific genetic alterations, such as in the following genes: CREEBP, KMT2D, STAT6, CARD11, CD79, TNFAIP3, CD58, CDKN2A or CDKN2B, TNFRSF4 and c-MYC (45,46,136-138).

Concerning miRNAs in FLs, a number of studies have demonstrated that there is an increase in the levels of 6 particular miRNAs: miR-223, miR-217, miR-222, miR221, let-7i and let-7b in patients with FL, in which their lymphoma underwent a transformation. In addition, the miR-17 92 cluster can be used as a useful diagnostic biomarker found in patients with FL, while miR-20a/b and miR-194 can also be found in patients with FL. Other useful diagnostic biomarkers in patients with FL may be the following: miR-9, miR-155, miR-31, miR-17, miR-217, miR-221, miR-222, miR-223, let-7i, let-7b17-miRNA signature, 44-miRNA signature, miR-494 23-miRNA signature (136-140) (Table III and Fig. 3).

Concerning lncRNAs in patients with FL, studies have demonstrated that there are 3-fold as many lncRNAs that are upregulated than lncRNAs that are downregulated in patients with FL3A stage disease, without their biological functions being cleared yet. The only lncRNA that seems to be upregulated in patients with FL3A grade disease is RP11-625 L16.3, located on chromosome 12, with an uncharacterized mode of action (72) (Table III and Fig. 2).

MCLs. MCL is recognizable as an aggressive and incurable small B-cell lymphoma. It predominantly affects older-aged males (>60 years old), and sometimes it may be indolent in some patients. MCLs arise from the mantle zone of early B-cells of the lymph node follicle and they possess the $t(11 ; 14)$ (q13;q32) translocation with an overexpression of cyclin D1.MCL cells also exhibit $\mathrm{CD}^{+}$and CD23- and surface IgM/D expression $(141,142)$.

Two types of clinically indolent variants have now been identified $(140,141)$. Classical MCL with IGHV-unmutated or minimally mutated B-cells and SOX11 overexpression; usually presented in lymph nodes and other extranodal sites. Additional molecular/cytogenetic abnormalities may be presented in blastoid or pleomorphic MCL. Leukemic non-nodal MCL 
Table IV. miRNAs and lncRNAs observed in patients with mantle-cell lymphoma.

\begin{tabular}{|c|c|c|c|c|}
\hline $\operatorname{miRNA}(\mathrm{s}) / \operatorname{lncRNA}$ & $\begin{array}{c}\text { Genome } \\
\text { location } \\
\text { (if defined) }\end{array}$ & Role/activation & Molecular mechanism/sample & (Refs.) \\
\hline MALAT1 & $11 \mathrm{q} 13$ & Oncogene & $\begin{array}{l}\text { Regulation of the bioavailability } \\
\text { of TGF- } \beta\end{array}$ & $(146-152)$ \\
\hline miR-15/16, miR-17/92 & & Diagnostic biomarker & Presence in cell lines & $(141,142)$ \\
\hline 95-miRNA signature & & Diagnostic biomarker & Presence in tissues & (143) \\
\hline $\begin{array}{l}\operatorname{miR}-15 b, \text { miR-129, } \operatorname{miR}-135, \text { miR-146a, } \\
\text { miR-424, miR-450, miR-222, miR-17, } \\
\text { miR-18a, miR-19b, miR-92a } \\
\text { (miR-17/92 cluster) }\end{array}$ & & Prognostic biomarkers & Presence in tissues & $(144,153)$ \\
\hline miR-29, miR-20b, miR-18b & & Prognostic biomarkers & Presence in cell lines and tissues & $(154-156)$ \\
\hline miR-223 & & Prognostic biomarkers & Presence in PBMCs and cell lines & (157) \\
\hline
\end{tabular}

lncRNA, long non-coding RNA; miRNA/miR, microRNA; PBMCs, peripheral blood mononuclear cells.

Table V. miRNAs and lncRNAs identified in patients with Burkitt's lymphoma.

\begin{tabular}{|c|c|c|c|c|}
\hline $\operatorname{miRNA}(\mathrm{s}) / \operatorname{lncRNA}$ & $\begin{array}{l}\text { Genome } \\
\text { location } \\
\text { (if defined) }\end{array}$ & Role/activation & Molecular mechanism/sample & (Refs.) \\
\hline MINCR & $8 \mathrm{q} 24.3$ & Uncharacterized & Induction of MYC & $(173)$ \\
\hline $\begin{array}{l}\text { miR-23a, miR-26a, miR-29b, } \\
\text { miR-30d, miR-146a, miR-146b, } \\
\text { miR-155, miR-221 }\end{array}$ & & Diagnostic biomarkers & Presence in tissues & $(165)$ \\
\hline $\begin{array}{l}\text { 22-miRNA signature, miR-513a, } \\
\text { miR-628, miR-9 }\end{array}$ & & Diagnostic biomarkers & Presence in tissues & $(166,167)$ \\
\hline $\begin{array}{l}\text { 39-miRNA signature, 19-miRNA } \\
\text { signature, 49-miRNA signature }\end{array}$ & & Diagnostic biomarkers & Presence in tissues & $(168-171)$ \\
\hline miR-34b, miR-29 family, miR-181b & & Diagnostic biomarkers & Presence in cell lines and tissues & $(167,171-173)$ \\
\hline
\end{tabular}

develops from IGHV-mutated SOX11 B-cells, and is usually presented in peripheral blood, BM and spleen (142).

Concerning miRNAs in MCLs, a number of studies have demonstrated the overexpression of miR-15/16 and miR-17 92 in MCL and that this is associated with an aggressive form of the disease $(143,144)$. In addition, the inhibition of miR-29 has been demonstrated to lead to the progression of MCL (a potential prognostic marker for MCL) (143-145). Additionally, the 95-miRNA signature can be a diagnostic biomarker for MCL (145) (Table IV and Fig. 3).

Concerning lncRNAs in patients with MCL, it has been demonstrated that MALAT1 is overexpressed in human MCL tissues and cell lines compared to normal B-cells [a high international prognostic index (IPI) is present], and is associated with the lower overall survival of patients with MCL (146). Thus, MALAT1, located on 11q13 chromosome, can act as an oncogene in patients with MCL (regulation of the bioavailability of TGF- $\beta$ ) (146-152) (Table IV and Fig. 2).
Finally, in Table IV, references of all the other miRNAs that have been observed in patients with MCL and used as prognostic biomarkers in clinical trials are presented (153-157).

$B L . \mathrm{BL}$ is a type of aggressive B-NHL. It may be presented with any of three main clinical variants: Endemic BL, sporadic BL and the immunodeficiency-associated BL (158). In all types of $\mathrm{BL}$, the dysregulation of the c-myc gene is observed (the gene is found at $8 \mathrm{q} 24$ ), presented with any one of the three known chromosomal translocations (159). The most common variant is $\mathrm{t}(8 ; 14)(\mathrm{q} 24 ; \mathrm{q} 32)$, which involves c-myc and IGH (159).

The variant at $\mathrm{t}(2 ; 8)(\mathrm{p} 12 ; \mathrm{q} 24)$ involves IGK and c-myc (160). The variant at $\mathrm{t}(8 ; 22)(\mathrm{q} 24 ; \mathrm{q} 11)$ involves IGL and c-myc (160). In addition, a last variant of three-way translocation, $\mathrm{t}(8 ; 14 ; 18)$ has been identified (161).

Concerning miRNAs in patients with BL, it seems that MYC regulates and is regulated by numerous miRNAs (Table V), the most common of which are the following: miR-23a, miR-26a, miR-29b, miR-30d, miR-146a, miR-146b, 
Table VI. miRNAs identified in patients with splenic marginal zone lymphoma B-cell lymphoma and mucosa-associated lymphoid tissue lymphoma.

\begin{tabular}{|c|c|c|c|c|c|}
\hline $\operatorname{miRNA}(\mathrm{s})$ & Disease type & $\begin{array}{l}\text { Genome } \\
\text { location }\end{array}$ & Role/activation & $\begin{array}{c}\text { Molecular } \\
\text { mechanism/sample }\end{array}$ & (Refs.) \\
\hline $\begin{array}{l}\operatorname{miR}-29 a, \text { miR-29b-1, miR-96, miR-129, } \\
\text { miR-182, miR-183, miR-335, miR-593 }\end{array}$ & $\begin{array}{l}\text { Splenic marginal } \\
\text { zone lymphoma }\end{array}$ & & $\begin{array}{l}\text { Diagnostic } \\
\text { biomarkers }\end{array}$ & Presence in tissues & $(174)$ \\
\hline $\begin{array}{l}\operatorname{miR}-127, \operatorname{miR}-139, \operatorname{miR}-335, \operatorname{miR}-411 \text {, } \\
\text { miR-451, miR-486 }\end{array}$ & $\begin{array}{l}\text { Splenic marginal } \\
\text { zone lymphoma }\end{array}$ & & $\begin{array}{l}\text { Diagnostic } \\
\text { biomarkers }\end{array}$ & Presence in tissues & $(175)$ \\
\hline $\begin{array}{l}\text { 27-miRNA signature, miR-142, } \\
\text { miR-155, miR-203 }\end{array}$ & $\begin{array}{l}\text { Mucosa-associated } \\
\text { lymphoid tissue }\end{array}$ & & $\begin{array}{l}\text { Diagnostic } \\
\text { biomarkers }\end{array}$ & Presence in tissues & $(176,177)$ \\
\hline miR-142, miR-155 & $\begin{array}{l}\text { Mucosa-associated } \\
\text { lymphoid tissue }\end{array}$ & & $\begin{array}{l}\text { Prognostic } \\
\text { biomarkers }\end{array}$ & Presence in tissues & (177) \\
\hline
\end{tabular}

miRNA/miR, microRNA.

miR-155, and miR-221 (162-165) [widely used as diagnostic biomarkers (166-173)] (Table V and Fig. 3).

Concerning lncRNAs in patients with BL, 13 lncRNAs have been identified thus far (173). The most well-identified lncRNA in patients with BL is MINCR, located on chromosome 8q24.3, with an uncharacterized role; but it seems that it causes the induction of myc and modulates its transcriptional program (173).

Other indolent BCNHLs. There are also two other types of BCNHLs which exhibit an indolent course. These are MALT lymphomas and MZL, particularly the splenic type (SMZL).

None of the lncRNAs has been thus far identified as playing a major role in the the activation or progression of a B-cell to transform in any of these types of B-cell lymphomas.

Concerning miRNAs in SMZL, miR-96, miR-129, miR-29a, miR-29b-1, miR-182, miR-183, miR-335 and miR-593 can be used as diagnostic biomarkers, although without sufficient data to date (174) (Table VI and Fig. 3).

As regards miRNAs in MALT lymphomas, miR-203 primarily, and secondly, miR-150, miR550, miR-124a, miR-518b and miR-539, have been widely recognizable as being present in gastric MALT lymphoma (175). Other miRNAs identified in MALT lymphomas are the following: The 27-miRNA signature, miR-142, miR-155, miR-203 miR-142 and miR-155 (176,177) (Table VI and Fig. 3).

b) HLs. There are two main types of HL: Classical Hodgkin lymphoma (9 out of 10 cases) and nodular lymphocyte predominant Hodgkin lymphoma (1 out of 10 cases) $(178,179)$. There is a differentiation in morphology, phenotype and molecular features between both these types. Furthermore, classical HL alone can be subclassified into 4 more pathologic subtypes: i) Nodular sclerosing HL; ii) mixed-cellularity subtype; iii) lymphocyte-rich; and iv) lymphocyte-depleted HL (180-182).

Compared to B-NHLs, only limited data are available on the expression of IncRNAs in HLs. As regards miRNAs in patients with HL Hodgkin, there are studies which show that low miR-135a levels lead to significantly poorer prognostic outcome in Hodgkin patients $(183,184)$. The inhibition of let-7 and miR-9 leads to the prevention of plasma cell differentiation (184). In particular, the inhibition of miR-9 seems to lead to a decrease in cytokine production and a reduced ability in attracting inflammatory cells (185). In addition, miR-155, the 23-miRNA signature and 134- and 100-miRNA signature, 25-miRNA signature and miR-9-2 (methylation) can be used as diagnostic biomarkers in patients with HL (as they are presented in HL cell lines and tissues) (186-193) (Table VII and Fig. 3).

c) T-NHLs and NK-NHLs. T-cell lymphomas affect T-cells and they are divided into 4 major types: i) Extranodal T-cell lymphoma; ii) cutaneous T-cell lymphomas: Sézary syndrome and Mycosis fungoides; iii) anaplastic large cell lymphoma; and iv) angioimmunoblastic T-cell lymphoma. There is also a clinical entity known as aggressive NK-cell leukemia with an aggressive, systemic proliferation of NK cells; it can also be termed aggressive NK-cell lymphoma $(194,195)$.

As regards miRNAs in T-cell and NK-cell lymphomas, very little is known so far. MiRNA-21, miRNA-155, miRNA-150, miRNA-142 and miRNA-494 are present in various forms of cutaneous T-cell lymphomas, compared to related benign disorders $(196,197)$. miRNA-146a and miRNA-155 are also present in patients with cutaneous T-cell lymphomas (1). miRNA-223, miRNA-BART-20, miRNA-BART-8, miRNA-BART-16 and miRNA-BART-9 are EBV-encoded and are associated with the activation of the EBV oncoprotein, LMP-1 (197-204) (Table VIII).

Concerning lncRNAs in various types of T-cell and NK-cell lymphomas, MALAT1, located on chromosome 11q13.1, has been identified as being overexpressed and leads to the induction of BMI1 activation (197); that is the reason why MALAT1 can be used as prognostic marker and therapeutic target in T- and NK-cell lymphomas (195) (Table VIII).

d) Other common B-cell malignancies. MM, also known as plasma cell myeloma, is a fatal malignant hematological disorder which lead to the proliferation of monoclonal antibody-secreting plasma cells; the main criterion is the presence of clonal plasma cells $>10 \%$ in bone marrow biopsy or in a biopsy from other tissues (plasmacytoma). MM accounts for $10 \%$ of all hematological malignancies (205).

Compared to all types of B-cell Lymphomas, very little is known about miRNA expression in patients with MM. As regards lncRNAs in patients with MM, the following have 
Table VII. miRNAs identified in patients with Hodgkin lymphoma.

\begin{tabular}{|c|c|c|c|c|}
\hline $\operatorname{miRNA}(\mathrm{s})$ & $\begin{array}{c}\text { Genome } \\
\text { location } \\
\text { (if defined) }\end{array}$ & Role/activation & $\begin{array}{l}\text { Molecular } \\
\text { mechanism/sample }\end{array}$ & (Refs.) \\
\hline miR-155 & & Diagnostic biomarkers & Presence in cell lines & $(185,186)$ \\
\hline $\begin{array}{l}\text { 23-miRNA signature, 134-miRNA signature, } \\
\text { 100-miRNA signature }\end{array}$ & & Diagnostic biomarkers & $\begin{array}{l}\text { Presence in cell lines } \\
\text { and tissues }\end{array}$ & $(187,188)$ \\
\hline 25-miRNA signature and miR-9-2 (methylation) & & Diagnostic biomarkers & Presence in tissues & $(189,190)$ \\
\hline $\operatorname{miR}-135 \mathrm{a}$ & & Prognostic biomarkers & $\begin{array}{l}\text { Presence in tissues } \\
\text { and cell lines }\end{array}$ & (191) \\
\hline $\begin{array}{l}\operatorname{miR}-21, \mathrm{miR}-30 \mathrm{e} / \mathrm{d}, \mathrm{miR}-92 \mathrm{~b}, \mathrm{miR}-124 \mathrm{a} \\
\text { (methylation) }\end{array}$ & & Prognostic biomarkers & Presence in tissues & $(192,193)$ \\
\hline
\end{tabular}

miRNA/miR, microRNA.

Table VIII. miRNAs and lncRNAs identified in patients with T-cell and NK-cell lymphomas.

\begin{tabular}{|c|c|c|c|c|c|}
\hline $\operatorname{miRNA}(\mathrm{s}) / \operatorname{lncRNA}$ & Disease type & $\begin{array}{l}\text { Genome } \\
\text { location } \\
\text { (if defined) }\end{array}$ & Role/activation & $\begin{array}{c}\text { Molecular } \\
\text { mechanism/sample }\end{array}$ & (Refs.) \\
\hline miRNA-21 & $\begin{array}{l}\text { NK-cell lymphoma- } \\
\text { derived cell lines } \\
\text { primary NKTCLs }\end{array}$ & & $\begin{array}{l}\text { New biomarker } \\
\text { or target in } \\
\text { thetreatment of } \\
\text { NKTCL. }\end{array}$ & $\begin{array}{l}\text { Regulation of apoptosis } \\
\text { of NK-cell lymphoma cell } \\
\text { lines via the PTEN/AKT } \\
\text { signaling pathway }\end{array}$ & $(199)$ \\
\hline miRNA-155 & $\begin{array}{l}\text { NK-cell lymphoma } \\
\text { cell lines Primary } \\
\text { NKTCL specimens }\end{array}$ & & $\begin{array}{l}\text { Potential molecular } \\
\text { marker of NKTCL }\end{array}$ & $\begin{array}{l}\text { Regulation of inflammation, } \\
\text { immune cells, and the } \\
\text { differentiation and } \\
\text { maturation of tumor cells }\end{array}$ & $(200)$ \\
\hline miRNA-142 & $\begin{array}{l}\text { Under-expression in } \\
\text { NKTCLs } \\
\text { lymphomas }\end{array}$ & & $\begin{array}{l}\text { Two different forms } \\
\text { (miRNA-142-3p and } \\
\text { miRNA-412-5p) } \\
\text { miRNA-142-3p is } \\
\text { a potential target of } \\
\text { therapy }\end{array}$ & $\begin{array}{l}\text { Downregulation of } \\
\text { RICTOR }\end{array}$ & $(201,202)$ \\
\hline miRNA-494 & NKTCLs & & $\begin{array}{l}\text { Potential target of } \\
\text { therapy }\end{array}$ & Downregulation of PTEN & $(202)$ \\
\hline miRNA-223 & NKTCLs & & EBV infection & Downregulation of PRDM1 & $(203)$ \\
\hline miRNA-16 & NKTCLs & & $\begin{array}{l}\text { Novel target in } \\
\text { NKTCL treatment }\end{array}$ & $\begin{array}{l}\text { Downregulation of } \\
\text { CDKN1A }\end{array}$ & $(197)$ \\
\hline miRNA-BART-20 & NKTCLs & & EBV-encoded & Maturation of NK-cells & $(204)$ \\
\hline miRNA-BART-8 & NKTCLs & & EBV-encoded & Induction of apoptosis & $(204)$ \\
\hline miRNA-BART-16 & NKTCLs & & EBV-encoded & $\begin{array}{l}\text { Induction of cell-cell } \\
\text { adhesion }\end{array}$ & $(204)$ \\
\hline miRNA-BART-9 & NKTCLs & & EBV-encoded & $\begin{array}{l}\text { Induction of cell } \\
\text { proliferation }\end{array}$ & $(204)$ \\
\hline MALAT1 & $\begin{array}{l}\text { Various types of T and } \\
\text { NK cell lymphomas }\end{array}$ & $11 \mathrm{q} 13.1$ & $\begin{array}{l}\text { Overexpression } \\
\text { Prognostic marker } \\
\text { and therapeutic } \\
\text { target in } \mathrm{T} \text { and } \mathrm{NK} \\
\text { cell lymphomas. }\end{array}$ & $\begin{array}{l}\text { Induction of BMI1 } \\
\text { activation }\end{array}$ & $(195)$ \\
\hline
\end{tabular}

lncRNA, long non-coding RNA; miRNA/miR, microRNA; NKTCL, natural-killer/T cell lymphoma. 
Table IX. IncRNAs identified in patients with multiple myeloma.

\begin{tabular}{|c|c|c|c|c|}
\hline $\operatorname{lncRNA}$ & $\begin{array}{l}\text { Genome } \\
\text { location }\end{array}$ & Role/activation & Molecular mechanism/sample & (Refs.) \\
\hline GAS5 & 1q25.1 & Tumor-suppressor & Regulation of mTOR pathway & $(77-86)$ \\
\hline DLEU2 & $13 \mathrm{q} 14.3$ & Tumor-suppressor & $\begin{array}{l}\text { Host of miR-15a/16-1 cluster and targeting } \\
\text { BCL2 }\end{array}$ & $(117-120)$ \\
\hline MALAT1 & $11 \mathrm{q} 13$ & Oncogene & Regulation of the bioavailability of TGF- $\beta$ & $(146-152)$ \\
\hline MEG3 & $14 \mathrm{q} 32.2$ & Tumor-suppressor & $\begin{array}{l}\text { Interaction with p53. } \\
\text { Regulation of P53 gene expression }\end{array}$ & $(206-209)$ \\
\hline TUG1 & $22 \mathrm{q} 12.2$ & Oncogene & Induction by p53 & $(150,152)$ \\
\hline lnc-SENP5-4/NCBP2-AS2 & $3 q 29$ & Uncharacterized & Not described & $(85)$ \\
\hline lnc-CPSF2-2 & $14 q 32$ & Uncharacterized & Not described & (85) \\
\hline Inc-LRRC47-1/TP73-AS1 & $1 \mathrm{p} 36$ & Uncharacterized & Not described & (85) \\
\hline lnc-ANGPTL1-3 & $1 \mathrm{q} 25$ & Uncharacterized & Not described & (85) \\
\hline lnc-WHSC2-2 & $4 \mathrm{p} 16.3$ & Uncharacterized & Not described & $(85)$ \\
\hline
\end{tabular}

lncRNA, long non-coding RNA.

been observed (Table IX): i) GAS5, located on chromosome 1q25.1, acting as a tumor-suppressor by regulating the mTOR pathway (77-86); ii) DLEU2, located on chromosome 13q14.3, acting as a tumor-suppressor by being a host of the miR-15a/16-1 cluster and targeting BCL2 (117-120); iii) 3) MALAT1, located on chromosome 11q13, acting as an oncogene by regulating the bioavailability of TGF- $\beta$ (146-152); iv) MEG3, located on chromosome 14q32.2, acting as a tumor-suppressor by interacting with p53 and regulating p53 gene expression (206-209); v) TUG1, located on chromosome $22 q 12.2$, acting as an oncogene by being induced by p53 (150,152); vi) lnc-SENP5-4/NCBP2-AS2, located on chromosome $3 \mathrm{q} 29$, with an uncharacterized mode of action (85); vii) 7) lnc-CPSF2-2, located on chromosome $14 \mathrm{q} 32$, with an uncharacterized mode of action (85); viii) lnc-LRRC47-1/TP73-AS1, located on chromosome 1p36, with an uncharacterized mode of action (85); ix) lnc-ANGPTL1-3, located on chromosome 1q25, with an uncharacterized mode of action (85); x) lnc-WHSC2-2, located on chromosome 4p16.3, with an uncharacterized mode of action (85).

\section{Anti-ncRNA therapeutic strategies in lymphoid disorders}

There are specific strategies that can be used in order to target ncRNAs in tumor management. These are the following: i) Antisense oligonucleotides (ASOs), which can trigger RNaseH-mediated RNA degradation (210); ii) CRISPR/Cas9 genome editing technique which can effectively silence the transcription of the lncRNA-expressing loci $(211,212)$; iii) viral vectors (adenovirus, lentivirus and retrovirus) which can be used as a RNA interference (RNAi) method and can lead to the knockdown of gene expression by neutralizing the targeted RNA through exogenous double-stranded RNA insertion (213-215); and iv) nanomedicine, including lipid-based nanoparticles (liposomes) (216), polymer-based nanoparticles and micelles (217), dendrimers (218), carbon-based nanoparticles (219), and metallic and magnetic nanoparticles, such as gold nanoparticles $(220,221)$.

All these novel therapeutic strategies targeting ncRNAs, have been tested to date in preclinical models with lymphoid disorders. For example, a viral vector carrying miR-28 has been delivered in DLBCL and BL xenografts and in murine models with B-lymphoma, with acceptable prophylactic and therapeutic effects (222).

Furthermore, the ASO strategy, such as LNA-anti-miR-155, has been used in a B-cell lymphoma murine model, exhibiting a significant effect in murine models (223). An anti-miR-155 oligonucleotide with the trademark Cobomarsen is currently being clinically nowadays in patients with cutaneous T-cell lymphoma (224).

Double-stranded RNAi and ASOs are the most commonly used lncRNA-targeted therapies. When the target lncRNA is localized in the nucleus, ASOs are the better therapeutic option (225).

The most important finding, by reviewing the literature, is that either the IncRNA expression signature or miRNA expression may help distinguish between the different lymphoma entities. In addition, as certain ncRNAs may be associated with the progression of lymphoma or drug resistance, these ncRNAs can be used as predictive and prognostic markers (225). However, the ncRNA regulatory network is complex and is not yet fully understood, as the majority of ncRNAs have not yet been thoroughly investigated. Nevertheless, ncRNA-based therapeutics can be combined, in the near future, with other techniques, such as chimeric antigen receptor (CAR) T-cell immunotherapy, the targeting of tumor cells, thus improving their therapeutic efficacy $(226,227)$.

\section{Conclusions and future perspectives}

Contemporary developments in biology have been combined with insightful discoveries analyzing the role of ncRNAs, either miRNAs or lncRNAs in human tumors, particularly lymphomas, such as: BCNHLs, HLs, T-cell/NK cell NHLs (T-/NK-cell NHLs) and other B-cell malignancies, such as MM.

The present review aimed to provide a thorough summary of the current understanding of ncRNAs in lymphoid malignancies by summarizing, for the first time, to the best of our knowledge, the whole existing ncRNA (and not into different categories), miRNAs and lncRNAs, which are associated with lymphoid disorders. 
The initial data suggest that mostly lncRNAs, play key roles in lymphangiogenesis, as a great number of them are deregulated in B-cell malignancies. However, this particular field is still in its infancy, with insufficient data; thus, further studies need to be performed.

Concerning the role of miRNAs as biomarkers in all lymphoid malignancies, ample data are available, although without immediate use in clinical practice. A number of miRNA biomarker studies to date on B-NHLs, HLs, T-/NK-NHLs and MM are not based on multi-center cooperations, and thus, in most cases, a number of reviews are non-overlapping and even contradictory.

For all the above reasons, further multi-center studies are warranted with the establishment of a standardized approach and the use of the same techniques: RT-qPCR, microarrays or next-generation sequencing (NGS). This is mandatory step in order to explore more thoroughly the role and functions of lncRNAs in normal B-cells and malignant B-cells; as well as to perform a more in-depth miRNA biomarker analysis in order to ensure that these molecules can be effectively used in daily practice. These tasks are both compelling and challenging in the next future for the prognosis and potential therapeutic targeting of all lymphoid malignancies; leading to a better treatment plan.

\section{Acknowledgements}

Not applicable.

\section{Funding}

No funding was received.

\section{Availability of data and materials}

Data sharing is not applicable to this article, as no datasets were generated or analyzed during the current study.

\section{Authors' contributions}

GD developed, planned, supervised the review and wrote the manuscript. MG created the figure and contributed to the writing of the manuscript. VZ supervised the review, contributed to the writing and revisions of the manuscript. DAS and SA collected relevant literature. VZ and GD confirm the authenticity of all the raw data All authors read and approved the final manuscript.

\section{Ethics approval and consent to participate}

Not applicable.

\section{Patient consent for publication}

Not applicable.

\section{Competing interests}

DAS is the Editor-in-Chief for the journal, but had no personal involvement in the reviewing process, or any influence in terms of adjudicating on the final decision, for this article. The other authors declare that they have no competing interests.

\section{References}

1. Bardia A and Seifter E: Johns Hopkins Patients' Guide to Lymphoma. 1st edition, Jones and Bartlett Publishers, Inc., pp138, 2010.

2. The Lymphoma Guide: Information for Patients and Caregivers. Leukemia and Lymphoma Society, New York, USA, 2013.

3. World Health Organization: World Cancer Report 2014. IARC Publications, Lyon, France, pp348-528, 2014.

4. Swerdlow SH, Campo E, Pileri SA, Harris NL, Stein H, Siebert R, Advani R, Ghielmini M, Salles GA, Zelenetz AD and Jaffe ES: The 2016 revision of the World Health Organization classification of lymphoid neoplasms. Blood 127: 2375-2390, 2016.

5. Coiffier B: Monoclonal antibody as therapy for malignant lymphomas. C R Biol 329: 241-254, 2006.

6. Siegel RL, Miller KD and Jemal A: Cancer statistics. CA Cancer J Clin 65: 5-29, 2015.

7. Küppers R, Klein U, Hansmann ML and Rajewsky K: Cellular origin of human B-cell lymphomas. N Engl J Med 341: 1520-1529, 1999.

8. National Cancer Institute: General information about adult Hodgkin Lymphoma, 2014.

9. National Cancer Institute: General Information about adult Non-Hodgkin Lymphoma, 2014.

10. Hu L, Luo D, Zhou T, Tao Y, Feng J and Mei S: The association between non-Hodgkin lymphoma and organophosphate pesticides exposure: A meta-analysis. Environ Pollut 231: 319-328, 2017.

11. Yang L, Dong J, Jiang S, Shi W, Xu X, Huang H, You X and Liu H: Red and processed meat consumption increases risk for Non-Hodgkin lymphoma: A PRISMA-compliant meta-analysis of observational studies. Medicine 94: e1729, 2015.

12. Solimini AG, Lombardi AM, Palazzo C and De Giusti M: Meat intake and non-Hodgkin lymphoma: A meta-analysis of observational studies. Cancer Causes Control 27: 595-606, 2016.

13. National Cancer Institute: Cancer Stat Facts: Non-Hodgkin Lymphoma, 2014.

14. Marcus R, Sweetenham J and Williams L (eds): Lymphoma: Pathology, diagnosis and treatment (2nd edition). Cambridge Medicine, p326, 2014.

15. Tepper JE, Niederhuber JO, Armitage JH, Doroshow MB and Kastan JE: Childhood Lymphoma (5th edition). Abeloff's Clinical Oncology. Chapter 97, Elsevier Inc., 2014.

16. Kamper-Jørgensen M, Rostgaard KG, Zahm SH, Cozen W, Smedby KE, Sanjosé S, Chang ET, Zheng T, La Vecchia C, Serraino D, et al: Cigarette smoking and risk of Hodgkin lymphoma and its subtypes: A pooled analysis from the International Lymphoma Epidemiology Consortium (InterLymph). Ann Oncol 24: 2245-2255, 2013.

17. Manli JN, Bennani N and Feldman AL: Lymphoma classification update: T-cell lymphomas, Hodgkin lymphoma, and histiocytic/ dendritic cell neoplasms. Expert Rev Hematol 10: 239-249, 2017.

18. Sheikhpour R, Pourhosseini F, Neamatzadeh H and Karimi R: Immunophenotype evaluation of Non-Hodgkin's lymphomas. Med J Islam Repub Iran 31: 121, 2017

19. Gibb EA, Brown CJ and Lam WL: The functional role of long non-coding RNA in human carcinomas. Mol Cancer 10: 38, 2011.

20. Taft RJ, Pang KC, Mercer TR, Dinger M and Mattick JS: Non-coding RNAs: Regulators of disease. J Pathol 220: 126-139, 2010.

21. Prensner JR and Chinnaiyan AM: The emergence of lncRNAs in cancer biology. Cancer Discov 1: 391-407, 2011.

22. Cao Q, Mani RS, Ateeq B, Dhanasekaran SM, Asangani IA and Prensner JR: Coordinated regulation of Polycomb Group Complexes through microRNAs in Cancer. Cancer Cell 20: 187-199, 2011.

23. He Y, Vogelstein B, Velculescu VE, Papadopoulos N and Kinzler KW: The antisense transcriptomes of human cells. Science 322: 1855-1857, 2008.

24. Faulkner GJ, Kimura Y, Daub CO, Wani S, Plessy C and Irvine KM: The regulated retrotransposon transcriptome of mammalian cells. Nat Genet 41: 563-571, 2009.

25. Pérez-Vera P, Reyes-León A and Fuentes-Pananá EM: Signaling proteins and transcription factors in normal and malignant early B cell development. Bone Marrow Res 2011: 502751, 2011.

26. Alberts B, Johnson A, Lewis J, Raff M, Roberts K and Walter P: Molecular Biology of the Cell. T cells and B cells derive their names from the organs in which they develop. T cells develop in the thymus, and B cells, in mammals, develop in the bone marrow in adults or the liver in fetuses. Garland Science: New York, NY, pg1367, 2002. 
27. Petri A, Dybkaer K, Bogsted M, Thrue CA, Hagedorn PH, Schmitz A, Bodker JS, Johnsen HE and Kauppinen S: Long noncoding RNA expression during Human B-cell development. PLoS One 10: e0138236, 2015.

28. Herzog S, Reth M and Jumaa H: Regulation of B-cell proliferation and differentiation by pre-B-cell receptor signalling. Nat Rey Immunol 9: 195-205, 2009

29. Graham LD, Pedersen SK, Brown GS, Ho T, Kassir Z Moynihan AT, Vizgoft EK, Dunne R, Pimlott L, Young GP, et al: Colorectal Neoplasia differentially expressed (CRNDE), a novel gene with elevated expression in colorectal adenomas and adenocarcinomas. Genes Cancer 2: 829-840, 2011

30. Ellis BC, Molloy PL and Graham LD: CRNDE: A long NonCoding RNA involved in CanceR, neurobiology, and development. Front Genet 3: 270, 2012

31. Ellis BC, Graham LD and Molloy PL: CRNDE, a long noncoding RNA responsive to insulin/IGF signaling, regulates genes involved in central metabolism. Biochim Biophys Acta 1843: 372-386, 2014.

32. Chen CZ, Li L, Lodish HF and Bartel DP: MicroRNAs modulate hematopoietic lineage differentiation. Science 303: 83-86, 2004

33. de Yebenes VG, Belver L, Pisano DG, Gonzalez S, Villasante A Croce $\mathrm{C}, \mathrm{He} \mathrm{L}$ and Ramiro AR: miR-181b negatively regulates activation-induced cytidine deaminase in B cells. J Exp Med 205: 2199-206, 2008

34. Teng G, Hakimpour P, Landgraf P, Rice A, Tuschl T, Casellas R and Papavasiliou FN: MicroRNA-155 is a negative regulator of activation-induced cytidine deaminase. Immunity 28: 621-629, 2008.

35. Smith A, Howell D, Patmore R, Jack A and Roman E: Incidence of haematological malignancy by sub-type: A report from the Haematological malignancy research network. Br J Cancer 105 1684-1692, 2011.

36. Li S, Young KH and Medeiros LJ: Diffuse large B-cell lymphoma. Pathology 50: 74-87, 2018.

37. Lenz G, Wright GW, Emre NC, Kohlhammer H, Dave SS, Davis RE, Carty S, Lam LT, Shaffer AL, Xiao W, et al: Molecular subtypes of diffuse large B-cell lymphoma arise by distinct genetic pathways. Proc Natl Acad Sci USA 105: 13520-13525, 2008.

38. Sukswai N, Lyapichev K, Khoury JD and Medeiros LJ: Diffuse large B-cell lymphoma variants: An update. Pathology 52: 53-67, 2019.

39. Shimada K, Hayakawa F and Kiyoi H: Biology and management of primary effusion lymphoma. Blood 132: 1879-1888, 2018.

40. Cheng Y, Xiao Y, Zhou R, Liao Y, Zhou J and Ma X: Prognostic significance of Helicobacter pylori-infection in gastric diffuse large B-cell lymphoma. BMC Cancer 19: 842, 2019.

41. Kuo SH, Yeh KH, Chen LT, Lin CW, Hsu PN, Hsu C, $\mathrm{Wu}$ MS, Tzeng YS, Tsai HJ, Wang HP and Cheng AL: Helicobacter pylori-related diffuse large B-cell lymphoma of the stomach: A distinct entity with lower aggressiveness and higher chemosensitivity. Blood Cancer J 4: e220, 2014.

42. Abramson JS: Hitting back at lymphoma: How do modern diagnostics identify high-risk diffuse large B-cell lymphoma subsets and alter treatment? Cancer 125: 3111-3120, 2019.

43. Chavez JC and Locke FL: CAR T cell therapy for B-cell lymphomas. Best Pract Res Clin Haematol 31: 135-146, 2018.

44. Liu Y and Barta SK: Diffuse large B-cell lymphoma: 2019 update on diagnosis, risk stratification, and treatment. Am J Hematol 94 604-616, 2019.

45. Roehle A,Hoefig KP,RepsilberD, Thorns C,Ziepert M, Wesche KO, Thiere M, Loeffler M, Klapper W, Pfreundschuh M, et al: MicroRNA signatures characterize diffuse large B-cell lymphomas and follicular lymphomas. Br J Haematol 142: 732-744, 2008.

46. Lawrie CH, Chi J, Taylor S, Tramonti D, Ballabio E, Palazzo S, Saunders NJ, Pezzella F, Boultwood J, Wainscoat JS and Hatton CS: Expression of microRNAs in diffuse large B cell lymphoma is associated with immunophenotype, survival and transformation from follicular lymphoma. J Cell Mol Med 13: 1248-1260, 2009.

47. Caramuta S, Lee L, Ozata DM, Akcakaya P, Georgii-Hemming P, Xie H, Amini RM, Lawrie CH, Enblad G, Larsson C, et al: Role of microRNAs and microRNA machinery in the pathogenesis of diffuse large B-cell lymphoma. Blood Cancer J 3: e152, 2013.

48. Lawrie CH, Saunders NJ, Soneji S, Palazzo S, Dunlop HM Cooper CD, Brown PJ, Troussard X, Mossafa H, Enver T, et al: MicroRNA expression in lymphocyte development and malignancy. Leukemia 22: 1440-1446, 2008

49. Zhong $\mathrm{H}, \mathrm{Xu} \mathrm{L}$, Zhong JH, Xiao F, Liu Q, Huang HH and Chen FY: Clinical and prognostic significance of miR-155 and $\mathrm{miR}-146 \mathrm{a}$ expression levels in formalin-fixed/paraffin-embedded tissue of patients with diffuse large B-cell lymphoma. Exp Ther Med 3: 763-770, 2012
50. Chapuy B, Stewart C, Dunford AJ, Kim J, Kamburov A, Redd RA, Lawrence MS, Roemer MGM, Li AJ, Ziepert M, et al: Molecular subtypes of diffuse large B cell lymphoma are associated with distinct pathogenic mechanisms and outcomes. Nat Med 24: 679-690, 2018

51. Zhou K, Feng X, Wang Y, Liu Y, Tian L, Zuo Z, Yi S, Wei X, Song Y and Qiu L: miR-223 is repressed and correlates with inferior clinical features in mantle cell lymphoma through targeting SOX11. Exp Hematol 58: 27-34, 2018.

52. Bouteloup M, Verney A, Rachinel N, Callet-Bauchu E, Ffrench M, Coiffier B, Magaud JP, Berger F, Salles GA and Traverse-Glehen A: MicroRNA expression profile in splenic marginal zone lymphoma. Br J Haematol 156: 279-281, 2012.

53. Fabbri M, Bottoni A, Shimizu M, Spizzo R, Nicoloso MS Rossi S, Barbarotto E, Cimmino A, Adair B, Wojcik SE, et al: Association of a microRNA/TP53 feedback circuitry with pathogenesis and outcome of B-cell chronic lymphocytic leukemia. JAMA 305: 59-67, 2011.

54. Hanke M, Hoefig K, Merz H, Feller AC, Kausch I, Jocham D, Warnecke JM and Sczakiel G: A robust methodology to study urine microRNA as tumor marker: microRNA-126 and microRNA-182 are related to urinary bladder cancer. Urol Oncol 28: 655-661, 2010.

55. He M, Gao L, Zhang S, Tao L, Wang J, Yang J and Zhu M: Prognostic significance of miR-34a and its target proteins of FOXP1, p53, and BCL2 in gastric MALT lymphoma and DLBCL. Gastric Cancer 17: 431-441, 2014.

56. Jia YJ, Liu ZB, Wang WG, Sun CB, Wei P, Yang YL, You MJ, Yu BH, Li XQ and Zhou XY: HDAC6 regulates microRNA-27b that suppresses proliferation, promotes apoptosis and target MET in diffuse large B-cell lymphoma. Leukemia 32: 703-711, 2017.

57. Gu L, Song G, Chen L, Nie Z, He B, Pan Y, Xu Y, Li R, Gao T, Cho WC and Wang S: Inhibition of miR-21 induces biological and behavioral alterations in diffuse large B-cell lymphoma. Acta Haematol 130: 87-94, 2013.

58. Zheng Z, Li X, Zhu Y, Gu W, Xie X and Jiang J: Prognostic significance of miRNA in patients with diffuse large B-cell lymphoma: A meta-analysis. Cell Physiol Biochem 39: 1891-1904, 2016.

59. Pillar N, Bairey O, Goldschmidt N, Fellig Y, Rosenblat Y, Shehtman I, Haguel D, Raanani P, Shomron N and Siegal T: MicroRNAs as predictors for CNS relapse of systemic diffuse large B-cell lymphoma. Oncotarget 8: 86020-86030, 2017.

60. Lawrie CH, Gal S, Dunlop HM, Pushkaran B, Liggins AP, Pulford K, Banham AH, Pezzella F, Boultwood J, Wainscoat JS, et al: Detection of elevated levels of tumourassociated microRNAs in serum of patients with diffuse large B-cell lymphoma. Br J Haematol 141: 672-675, 2008.

61. Bomben R, Gobessi S, Dal Bo M, Volinia M, Marconi D, Tissino E, Benedetti D, Zucchetto A, Rossi D, Gaidano G, et al: The miR-17 92 family regulates the response to Toll-like receptor 9 triggering of CLL cells with unmutated IGHV genes. Leukemia 26: 1584-1593, 2012.

62. Calin GA, Ferracin M, Cimmino A, Di Leva GD, Shimizu M, Wojcik SE, Iorio MV, Visone R, Sever NI, Fabbri M, et al: A microRNA signature associated with prognosis and progression in chronic lymphocytic leukemia. N Engl J Med 353: 1793-1801, 2005.

63. Ferrajoli A, Shanafelt TD, Ivan C, Ivan C, Shimizu M, Rabe KG, Nouraee N, Ikuo M, Ghosh AK, Lerner S, et al: Prognostic value of miR-155 in individuals with monoclonal B-cell lymphocytosis and patients with B chronic lymphocytic leukemia. Blood 122: 1891-1899, 2013

64. Iqbal J, Shen Y, Huang X, Liu Y, Wake L, Liu C, Deffenbacher K, Lachel CM, Wang C, Rohr J, et al: Global microRNA expression profiling uncovers molecular markers for classification and prognosis in aggressive B-cell lymphoma. Blood 125: 1137-1145, 2015.

65. Ferracin M, Zagatti B, Rizzotto L, Cavazzini F, Veronese A, Ciccone M, Saccenti E, Lupini L, Grilli A, De Angeli C, et al: MicroRNAs involvement in fludarabine refractory chronic lymphocytic leukemia. Mol Cancer 9: 123, 2010.

66. Khare D, Goldschmidt N, Bardugo A, Gur-Wahnon D Ben-Dov IZ and Avni B: Plasma microRNA profiling: Exploring better biomarkers for lymphoma surveillance. PLoS One 12: e0187722, 2017.

67. Meng Y, Quan L and Liu A: Identification of key microRNAs associated with diffuse large B-cell lymphoma by analyzing serum microRNA expressions. Gene 642: 205-211, 2018.

68. Song G, Gu L, Li J, Tang Z, Liu H, Chen B, Sun X, He B, Pan Y, Wang S and Cho WC: Serum microRNA expression profiling predict response to $\mathrm{R}-\mathrm{CHOP}$ treatment in diffuse large $\mathrm{B}$ cell lymphoma patients. Ann Hematol 93: 1735-1743, 2014. 
69. Leivonen SK, Icay K, Jäntti K, Siren I, Liu C, Alkodsi A, Cervera A, Ludvigsen M, Hamilton-Dutoit SJ, d'Amore F, et al: MicroRNAs regulate key cell survival pathways and mediate chemosensitivity during progression of diffuse large B-cell lymphoma. Blood Cancer J 7: 654, 2017.

70. Thompson MA, Edmonds MD, Liang S, McClintock-Treep S, Wang X, Li S and Eischen CM: miR-31 and miR-17-5p levels change during transformation of follicular lymphoma. Human Pathol 50: 118-126, 2016.

71. Leich E,Zamo A,Horn H,Haralambieva E, Puppe B, Gascoyne RD, Chan WC, Braziel RM, Rimsza LM, Weisenburger DD, et al: MicroRNA profiles of $\mathrm{t}(14 ; 18)$-negative follicular lymphoma support a late germinal center B-cell phenotype. Blood 118: 5550-5558, 2011.

72. Peng W, Wu J and Feng J: LincRNA-p21 predicts favorable clinical outcome and impairs tumorigenesis in diffuse large B cell lymphoma patients treated with R-CHOP chemotherapy. Clin Exp Med 17: 1-8, 2017.

73. Blume CJ, Hotz-Wagenblatt A, Hullein J, Sellner L, Jethwa A, Stolz T, Slabicki M, Lee K, Sharathchandra A, Benner A, et al: p53-dependent non-coding RNA networks in chronic lymphocytic leukemia. Leukemia 29: 2015-2023, 2015.

74. Huarte M, Guttman M, Feldser D, Garber M, Koziol MJ, Kenzelmann-Broz D, Khalil AM, Zuk O, Amit I, Rabani M, et al: A large intergenic noncoding RNA induced by p53 mediates global gene repression in the p53 response. Cell 142: 409-419, 2010.

75. Yoon JH, Abdelmohsen K, Srikantan S, Yang X, Martindale JL, De S, Huarte $\mathrm{M}$, Zhan $\mathrm{M}$, Becker $\mathrm{KG}$ and Gorospe $\mathrm{M}$ : LincRNA-p21 suppresses target mRNA translation. Mol Cell 47: 648-655, 2012.

76. Peponi E, Drakos E, Reyes G, Leventaki V, Rassidakis GZ and Medeiros LJ: Activation of mammalian target of rapamycin signaling promotes cell cycle progression and protects cells from apoptosis in mantle cell lymphoma. The Am J Pathol 169: 2171-2180, 2006.

77. Mourtada-Maarabouni $M$ and Williams GT: Role of GAS5 noncoding RNA in mediating the effects of rapamycin and its analogues on mantle cell lymphoma cells. Clin Lymphoma Myeloma Leuk 14: 468-473, 2014.

78. Coccia EM, Cicala C, Charlesworth A, Ciccarelli C, Rossi GB Philipson L and Sorrentino V: Regulation and expression of a growth arrest-specific gene (gas5) during growth, differentiation, and development. Mol Cell Biol 12: 3514-3521, 1992.

79. Mourtada-Maarabouni M, Pickard MR, Hedge VL, Farzaneh F and Williams GT: GAS5, a non-protein-coding RNA, controls apoptosis and is downregulated in breast cancer. Oncogene 28: 195-208, 2009.

80. Nakamura Y, Takahashi N, Kakegawa E, Yoshida K, Ito Y, Kayano H, Niitsu N, Jinnai I and Bessho M: The GAS5 (growth arrest-specific transcript 5) gene fuses to BCL6 as a result of $\mathrm{t}(1 ; 3)(\mathrm{q} 25 ; \mathrm{q} 27)$ in a patient with B-cell lymphoma. Cancer Genet Cytogenet 182: 144-149, 2008.

81. Qiao HP, Gao WS, Huo JX and Yang ZS: Long non-coding RNA GAS5 functions as a tumor suppressor in renal cell carcinoma. Asian Pac J Cancer Prev 14: 1077-1082, 2013.

82. Shi X, Sun M, Liu H, Yao Y, Kong R, Chen F and Song Y: A critical role for the long non-coding RNA GAS5 in proliferation and apoptosis in non-small-cell lung cancer. Mol Carcinog 54 (Suppl 1): E1-E12, 2015.

83. Williams GT, Mourtada-Maarabouni M and Farzaneh F: A critical role for non-coding RNA GAS5 in growth arrest and rapamycin inhibition in human T-lymphocytes. Biochem Soc Trans 39: 482-486, 2011

84. Mourtada-Maarabouni M, Hasan AM, Farzaneh F and Williams GT: Inhibition of human T-cell proliferation by mammalian target of rapamycin (mTOR) antagonists requires noncoding RNA growth-arrest-specific transcript 5 (GAS5). Mol Pharmacol 78: 19-28, 2010.

85. Ronchetti D, Agnelli L, Taiana E, Galletti S, Manzoni M, Todoerti K, Musto P, Strozzi F and Neri A: Distinct lncRNA transcriptional fingerprints characterize progressive stages of multiple myeloma. Oncotarget 7: 14814-14830, 2016.

86. Kino T, Hurt DE, Ichijo T, Nader N and Chrousos GP: Noncoding RNA gas5 is a growth arrest- and starvationassociated repressor of the glucocorticoid receptor. Sci Signal 3: ra8, 2010

87. Conde L, Riby J, Zhang J, Bracci PM and Skibola CF: Copy number variation analysis on a non-Hodgkin lymphoma case-control study identifies an 11q25 duplication associated with diffuse large B-cell lymphoma. PLoS One 9: e105382, 2014.
88. Lu Z, Pannunzio NR, Greisman HA, Casero D, Parekh C and Lieber MR: Convergent BCL6 and lncRNA promoters demarcate the major breakpoint region for BCL6 translocations. Blood 126: 1730-1731, 2015.

89. Peng W and Feng J: Long noncoding RNA LUNAR1 associates with cell proliferation and predicts a poor prognosis in diffuse large B-cell lymphoma. Biomed Pharmacother 77: 65-71, 2016

90. Trimarchi T, Bilal E, Ntziachristos P, Fabbri G, DallaFavera R, Tsirigos A and Aifantis I: Genome-wide mapping and characterization of Notch-regulated long noncoding RNAs in acute leukemia. Cell 158: 593-606, 2014.

91. Peng W, Fan H, Wu G, Wu J and Feng J: Upregulation of long noncoding RNA PEG10 associates with poor prognosis in diffuse large B cell lymphoma with facilitating tumorigenicity. Clin Exp Med 16: 177-182, 2016.

92. Ono R, Kobayashi S, Wagatsuma H, Aisaka K, Kohda T, Kaneko-Ishino T and Ishino F: A retrotransposon-derived gene, PEG10, is a novel imprinted gene located on human chromosome 7q21. Genomics 73: 232-237, 2001.

93. Li CM, Margolin AA, Salas M, Memeo L, Mansukhani M, Hibshoosh H, Szabolcs M, Klinakis A and Tycko B: PEG10 is a c-MYC target gene in cancer cells. Cancer Res 66: 665-672, 2006.

94. Peng W, Wu J and Feng J: Long noncoding RNA HULC predicts poor clinical outcome and represents pro-oncogenic activity in diffuse large B-cell lymphoma. Biomed Pharmacother 79: 188-193, 2016.

95. Hammerle M, Gutschner T, Uckelmann H, Ozgur S, Fiskin E, Gross M, Skawran B, Geffers R, Longerich T, Breuhahn K, et al: Posttranscriptional destabilization of the liver-specific long noncoding RNA HULC by the IGF2 mRNA-binding protein 1 (IGF2BP1). Hepatology 58: 1703-1712, 2013.

96. Xie $\mathrm{H}$, Ma $\mathrm{H}$ and Zhou D: Plasma HULC as a promising novel biomarker for the detection of hepatocellular carcinoma. Biomed Res Int 2013: 136106, 2013.

97. Peng W, Gao W and Feng J: Long noncoding RNA HULC is a novel biomarker of poor prognosis in patients with pancreatic cancer. Med Oncol 31: 346, 2014.

98. Yan Y, Han J, Li Z, Yang H, Sui Y and Wang M: Elevated RNA expression of long noncoding HOTAIR promotes cell proliferation and predicts a poor prognosis in patients with diffuse large B cell lymphoma. Mol Med Rep 13: 5125-5131, 2016.

99. Hallek M, Shanafelt TD and Eichhorst B: Chronic lymphocytic leukaemia. Lancet 391: 1524-1537, 2018.

100. Tresckow JV, Eichhorst B, Bahlo J and Hallek M: The treatment of chronic lymphatic leukemia. Dtsch Arztebl Int 116: 41-46, 2019.

101. Choi SM and O'Malley DP: Diagnostically relevant updates to the WHO classification of lymphoid neoplasms. Ann Diagn Pathol 37: 67-74, 2018.

102. Matutes E, Owusu-Ankomah K, Morilla R, Garcia Marco J, Houlihan A, Que TH and Catovsky D: The immunological profile of B-cell disorders and proposal of a scoring system for the diagnosis of CLL. Leukemia 8: 1640-1645, 1994.

103. Hallek M: Chronic lymphocytic leukemia: Update on diagnosis, risk stratification, and treatment. Am J Hematol 92: 946-965, 2017.

104. Deans JP and Polyak MJ: FMC7 is an epitope of CD20. Blood 111: 2492, 2008.

105. Palumbo GA, Parrinello N, Fargione G, Cardillo K, Chiarenza A, Berretta S, Conticello C, Villari L and Di Raimondo F: CD200 expression may help in differential diagnosis between mantle cell lymphoma and B-cell chronic lymphocytic leukemia. Leuk Res 33: 1212-1216, 2009.

106. Calin GA, Dumitru CD, Shimizu M, Bichi R, Zupo S, Noch E, Aldler H, Rattan S, Keating M, Rai K, et al: Frequent deletions and down-regulation of micro-RNA genes miR15 and miR16 at 13 q14 in chronic lymphocytic leukemia. Proc Natl Acad Sci USA 99: 15524-15529, 2002.

107. Sampath D, Liu C, Vasan K, Sulda M, Puduvalli VK, Wierda WG and Keating MJ: Histone deacetylases mediate the silencing of miR-15a, miR-16, and miR-29b in chronic lymphocytic leukemia. Blood 119: 1162-1172, 2012.

108. Rossi S, Shimizu M, Barbarotto E, Nicoloso MS, Dimitri F, Sampath D, Fabbri M, Lerner S, Barron LL, Rassenti LZ, et al: MicroRNA fingerprinting of CLL patients with chromosome $17 \mathrm{p}$ deletion identify a miR-21 score that stratifies early survival. Blood 116: 945-952, 2010.

109. Visone R, Veronese A, Balatti V and Croce CM: MiR-181b: New perspective to evaluate disease progression in chronic lymphocytic leukemia. Oncotarget 3: 195-202, 2012. 
110. Cui B, Chen L, Zhang S, Mraz M, Fecteau JF, Yu J, Ghia EM, Zhang L, Bao L, Rassenti LZ, et al: MicroRNA-155 influences $\mathrm{B}$-cell receptor signaling and associates with aggressive disease in chronic lymphocytic leukemia. Blood 124: 546-554, 2014

111. Caivano A, La Rocca F, Simeon V, Girasole M, Dinarelli S, Laurenzana I, De Stradis A, De Luca L, Trino S, Traficante A, et al: MicroRNA-155 in serum-derived extracellular vesicles as a potential biomarker for hematologic malignancies-a short report Cell Oncol (Dordr) 40: 97-103, 2017.

112. Filip AA, Grenda A, Popek S, Koczkodaj D, Wojnowska MM, Budzyński M, Szczepanek EW, Zmorzyński S, Karczmarczyk A and Giannopoulos K: Expression of circulating miRNAs associated with lymphocyte differentiation and activation in CLL-another piece in the puzzle. Ann Hematol 96: 33-50, 2017.

113. Gaidano G, Foà R and Dalla-Favera R: Molecular pathogenesis of chronic lymphocytic leukemia. J Clin Invest 122: 3432-3438, 2012.

114. Dohner H, Stilgenbauer S, Benner A, Leupolt E, Krober A, Bullinger L, Dohner K, Bentz M and Lichter P: Genomic aberrations and survival in chronic lymphocytic leukemia. N Eng J Med 343: 1910-1916, 2000

115. Cimmino A, Calin GA, Fabbri M, Iorio MV, Ferracin M, Shimizu M, Wojcik SE, Aqeilan RI, Zupo S, Dono M, et al: miR-15 and miR16 induce apoptosis by targetinag BCL2. Proc Natl Acad Sci USA 102: 13944-13949, 2005.

116. Fathullahzadeh S, Mirzaei H, Honardoost MA, Sahebkar A and Salehi M: Circulating microRNA-192 as a diagnostic biomarker in human chronic lymphocytic leukemia. Cancer Gene Ther 23: 327-332, 2016

117. Klein U, Lia M, Crespo M, Siegel R, Shen Q, Mo T, Ambesi-Impiombato A, Califano A, Migliazza A, Bhagat $G$ and Dalla-Favera R: The DLEU2/miR-15a/16-1 cluster controls B cell proliferation and its deletion leads to chronic lymphocytic leukemia. Cancer Cell 17: 28-40, 2010

118. Lerner M, Harada M, Loven J, Castro J, Davis Z, Oscier D, Henriksson M, Sangfelt O, Grander D and Corcoran MM: DLEU2, frequently deleted in malignancy, functions as a critical host gene of the cell cycle inhibitory microRNAs miR-15a and miR-16-1. Exp Cell Res 315: 2941-2952, 2009

119. Garding A, Bhattacharya N, Claus R, Ruppel M, Tschuch C, Filarsky K, Idler I, Zucknick M, Caudron-Herger M, Oakes C, et al: Epigenetic upregulation of lncRNAs at 13q14.3 in leukemia is linked to the In Cis downregulation of a gene cluster that targets NF-kB. PLoS Genet 9: e1003373, 2013

120. Baer C, Oakes CC and Ruppert AS: Epigenetic silencing of miR-708 enhances NF- $\mathrm{BB}$ signaling in chronic lymphocytic leukemia. Int J Cancer 137: 1352-1361, 2015

121. Clemson CM, Hutchinson JN, Sara SA, Ensminger AW, Fox AH, Chess A and Lawrence JB: An architectural role for a nuclear noncoding RNA: NEAT1 RNA is essential for the structure of paraspeckles. Mol Cell 33: 717-726, 2009.

122. Naganuma T, Nakagawa S, Tanigawa A, Sasaki YF, Goshima N and Hirose T: Alternative 3 '-end processing of long noncoding RNA initiates construction of nuclear paraspeckles. EMBO J 31: 4020-4034, 2012.

123. Sattari A, Siddiqui H, Moshiri F, Ngankeu A, Nakamura T, Kipps TJ and Croce CM: Upregulation of long noncoding RNA MIAT in aggressive form of chronic lymphocytic leukemias. Oncotarget 7: 54174-54182, 2016

124. Ishii N, Ozaki K, Sato H, Mizuno H, Saito S, Takahashi A, Miyamoto Y, Ikegawa S, Kamatani N, Hori M, et al: Identification of a novel noncoding RNA, MIAT, that confers risk of myocardial infarction. J Hum Genet 51: 1087-1099, 2006.

125. Ip JY and Nakagawa S: Long non-coding RNAs in nuclear bodies. Dev Growth Differ 54: 44-54, 2012.

126. Sheik Mohamed J, Gaughwin PM, Lim B, Robson P and Lipovich L: Conserved long noncoding RNAs transcriptionally regulated by Oct4 and Nanog modulate pluripotency in mouse embryonic stem cells. RNA 16: 324-337, 2010.

127. Ferreira PG, Jares P, Rico D, Gomez-López G, Martínez-Trillos A, Villamor N, Ecker S, Gonzalez-Perez A, Knowles DG, Monlong J, et al: Transcriptome characterization by RNA sequencing identifies a major molecular and clinical subdivision in chronic lymphocytic leukemia. Genome Res 24: 212-226, 2014.

128. Ronchetti D, Manzoni M, Agnelli L and Vinci C: lncRNA profiling in early-stage chronic lymphocytic leukemia identifies transcriptional fingerprints with relevance in clinical outcome. Blood Cancer J 6: e468, 2016.

129. Park SM, Park SJ, Kim HJ, Kwon OH, Kang TW, Sohn HA, Kim SK, Moo Noh S, Song KS, Jang SJ, et al: A known expressed sequence tag, BM742401, is a potent lincRNA inhibiting cancer metastasis. Exp Mol Med 45: e31, 2013.
130. Wang LQ, Wong KY, Li ZH and Chim CS: Epigenetic silencing of tumor suppressor long non-coding RNA BM742401 in chronic lymphocytic leukemia. Oncotarget 7: 82400-82410, 2016

131. Eis PS, Tam W, Sun L, Chadburn A, Li Z, Gomez MF, Lund E and Dahlberg JE: Accumulation of miR-155 and BIC RNA in human B cell lymphomas. Proc Natl Acad Sci USA 102: 3627-3632, 2005.

132. Tam W: Identification and characterization of human BIC, a gene on chromosome 21 that encodes a noncoding RNA. Gene 274: $157-167,2001$.

133. Elton TS, Selemon H, Elton SM and Parinandi NL: Regulation of the MIR155 host gene in physiological and pathological processes. Gene 532: 1-12, 2013.

134. Stamatopoulos B, Van Damme M, Crompot E, Dessars B, Housni HE, Mineur P, Meuleman N, Bron D and Lagneaux L: Opposite prognostic significance of cellular and serum circulating MicroRNA-150 in patients with chronic lymphocytic leukemia. Mol Med 21: 123-133, 2015.

135. Georgiadis P, Liampa I, Hebels DG, Krauskopf J, Chatziioannou A, Valavanis I, de Kok TMCM, Kleinjans JCS, Bergdahl IA, Melin B, et al: Evolving DNA methylation and gene expression markers of B-cell chronic lymphocytic leukemia are present in pre-diagnostic blood samples more than 10 years prior to diagnosis. BMC Genomics 18: 728, 2017.

136. Gascoyne RD, Nadel B, Pasqualucci L, Fitzgibbon J, Payton JE Melnick A, Weigert O, Tarte K, Gribben JG, Friedberg JW, et al: Follicular lymphoma: State-of-the-art ICML workshop in Lugano 2015. Hematological Oncol 35: 397-407, 2017.

137. Boughan K and Caimi PF: Follicular lymphoma: Diagnostic and prognostic considerations in initial treatment approach. Curr Oncol Rep 21: 63, 2019

138. Pan Y, Li H, Guo Y, Luo Y, Li H, Xu Y, Deng J and Sun B: A pilot study of long noncoding RNA expression profiling by microarray in follicular lymphoma. Gene 577: 132-139, 2016.

139. Wang W, Corrigan-Cummins M, Hudson J, Maric I, Simakova O Neelapu SS, Kwak LW, Janik JE, Gause B, Jaffe ES and Calvo KR: MicroRNA profiling of follicular lymphoma identifies microRNAs related to cell proliferation and tumor response. Haematologica 97: 586-594, 2012

140. Arribas AJ, Campos-Martín Y, Gómez-Abad C, Algara P, Sánchez-Beato M, Rodriguez-Pinilla MS, Montes-Moreno S, Martinez N, Alves-Ferreira J, Piris MA and Mollejo M: Nodal marginal zone lymphoma: Gene expression and miRNA profiling identify diagnostic markers and potential therapeutic targets. Blood 119: e9-e21, 2012.

141. Jares P, Colomer D and Campo E: Molecular pathogenesis of mantle cell lymphoma. J Clin Invest 122: 3416-3423, 2012.

142. Carvajal-Cuenca A, Sua LF, Silva NM, Pittaluga S, Royo C, Song JY, Sargent RL, Espinet B, Climent F, Jacobs SA, et al: In situ mantle cell lymphoma: Clinical implications of an incidental finding with indolent clinical behavior. Haematologica 97: 270-278, 2012

143. Navarro A, Beà S, Fernández V, Prieto M, Salaverria I, Jares P, Hartmann E, Mozos A, López-Guillermo A, Villamor N, et al: MicroRNA expression, chromosomal alterations, and immunoglobulin variable heavy chain hypermutations in Mantle cell lymphomas. Cancer Res 69: 7071-7078, 2009.

144. Chen RW, Bemis LT, Amato CM, Myint H, Tran H, Birks DK, Eckhardt SG and Robinson WA: Truncation in CCND1 mRNA alters miR-16-1 regulation in mantle cell lymphoma. Blood 112: 822-829, 2008

145. Iqbal J, Shen Y, Liu Y, Fu K, Jaffe ES, Liu C, Liu Z, Lachel CM, Deffenbacher K, Greiner TC, et al: Genome-wide miRNA profiling of mantle cell lymphoma reveals a distinct subgroup with poor prognosis. Blood 119: 4939-4948, 2012.

146. Wang X, Sehgal L, Jain N, Khashab T, Mathur R and Samaniego F: LncRNA MALAT1 promotes development of mantle cell lymphoma by associating with EZH2. J Transl Med 14: 346, 2016

147. Tripathi V, Ellis JD, Shen Z, Song DY, Pan Q, Watt AT, Freier SM, Bennett CF, Sharma A, Bubulya PA, et al: The nuclear-retained noncoding RNA MALAT1 regulates alternative splicing by modulating SR splicing factor phosphorylation. Mol Cell 39: 925-938, 2010

148. Yang F, Yi F, Han X, Du Q and Liang Z: MALAT-1 interacts with hnRNP C in cell cycle regulation. FEBS Lett 587: 3175-3181, 2013.

149. Cho SF, Chang YC, Chang CS, Lin SF, Liu YC, Hsiao HH, Chang JG and Liu TC: MALAT1 long non-coding RNA is overexpressed in multiple myeloma and may serve as a marker to predict disease progression. BMC Cancer 14: 809, 2014. 
150. Isin M, Ozgur E, Cetin G, Erten N, Aktan M, Gezer U and Dalay $\mathrm{N}$ : Investigation of circulating lncRNAs in B-cell neoplasms. Clin Chim Acta 431: 255-259, 2014.

151. Li B, Chen P, Qu J, Shi L, Zhuang W, Fu J, Li J, Zhang X, Sun Y and Zhuang W: Activation of LTBP3 gene by a long noncoding RNA (lncRNA) MALAT1 transcript in mesenchymal stem cells from multiple myeloma. J Biol Chem 289: 29365-29375, 2014.

152. Matsumoto T and Abe M: TGF- $\beta$-related mechanisms of bone destruction in multiple myeloma. Bone 48: 129-134, 2011.

153. Arakawa F, Kimura Y, Yoshida N, Miyoshi H, Doi A, Yasuda K, Nakajima K, Kiyasu J, Niino D, Sugita Y, et al: Identification of miR-15b as a transformation-related factor in mantle cell lymphoma. Int J Oncol 48: 485-492, 2016.

154. Roisman A, Huamán Garaicoa F, Metrebian F, Narbaitz M, Kohan D, García Rivello H, Fernandez I, Pavlovsky A, Pavlovsky M, Hernández L and Slavutsky I: SOXC and miR17-92 gene expression profiling defines two subgroups with different clinical outcome in mantle cell lymphoma. Genes Chromosomes Cancer 55: 531-540, 2016.

155. Zhao JJ, Lin J, Lwin T, Yang H, Guo J, Kong W, Dessureault S, Moscinski LC, Rezania D, Dalton WS, et al: microRNA expression profile and identification of miR-29 as a prognostic marker and pathogenetic factor by targeting CDK6 in mantle cell lymphoma. Blood 115: 2630-2639, 2010.

156. Di Lisio L, Gomez-López G, Sánchez-Beato M, Gómez-Abad C, Rodrıguez ME, Villuendas R, Ferreira BI, Carro A, RicoD, Mollejo M, et al: Mantle cell lymphoma: Transcriptional regulation by microRNAs. Leukemia 24: 1335-1342, 2010.

157. Husby S, Ralfkiaer U, Garde C, Zandi R, Ek S, Kolstad A, Jerkeman M, Laurell A, Räty R, Pedersen LB, et al: miR-18b overexpression identifies mantle cell lymphoma patients with poor outcome and improves the MIPI-B prognosticator. Blood 125: 2669-2677, 2015

158. Molyneux E, Rochford R, Griffin B, Newton R, Jackson G, Menon G, Harrison C, Israels $\mathrm{T}$ and Bailey S: Burkitt's lymphoma. Lancet 379: 1234-1244, 2012.

159. Hoffman R: Hematology: Basic Principles and Practice (5th edition) Churchill Livingstone/Elsevier, Philadelphia, PA, pp1304-1305, 2009.

160. Smardova J, Grochova D, Fabian P, Moulis M, Smarda J, Falkova I, Ravcukova B, Vankova J and Vasova I: An unusual p53 mutation detected in Burkitt's lymphoma: 30 bp duplication. Oncol Rep 20: 773-778, 2008.

161. Liu D, Shimonov J, Primanneni S, Lai Y, Ahmed T and Seiter K: $\mathrm{t}(8 ; 14 ; 18)$ : A 3-way chromosome translocation in two patients with Burkitt's lymphoma/leukemia. Mol Cancer 6: 35, 2007.

162. Dorsett Y, McBride KM, Jankovic M, Gazumyan A, Thai TH, Robbiani DF, Di Virgilio M, Reina San-Martin B, Heidkamp G, Schwickert TA, et al: MicroRNA-155 suppresses activation-induced cytidine deaminase-mediated Myc-Igh translocation. Immunity 28: 630-638, 2008.

163. Gao P, Tchernyshyov I, Chang TC, Lee YS, Kita K, Ochi T, Zeller KI, De Marzo AM, Van Eyk JE, Mendell JT and Dang CV: c-Myc suppression of miR-23a/b enhances mitochondrial glutaminase expression and glutamine metabolism. Nature 458: 762-765, 2009.

164. Leucci E, Cocco M, Onnis A, De Falco G, van Cleef P, Bellan C, van Rijk A, Nyagol J, Byakika B, Lazzi S, et al: MYC translocation-negative classical Burkitt lymphoma cases: An alternative pathogenetic mechanism involving miRNA deregulation. J Pathol 216: 440-450, 2008.

165. Lenze D, Leoncini L, Hummel M, Volinia S, Liu CG, Amato T, De Falco G, Githanga J, Horn H, Nyagol J, et al. The different epidemiologic subtypes of Burkitt lymphoma share a homogenous micro RNA profile distinct from diffuse large B-cell lymphoma. Leukemia 25: 1869-1876, 2011.

166. Hezaveh K, Kloetgen A, Bernhart SH, Mahapatra KD, Lenze D, Richter J, Haake A, Bergmann AK, Brors B, Burkhardt B, et al: Alterations of microRNA and microRNA-regulated messenger RNA expression in germinal center B-cell lymphomas determined by integrative sequencing analysis. Haematologica 101: 1380-1389, 2016.

167. Chang TC, Yu D, Lee YS, Wentzel EA, Arking DE, West KM, Dang CV, Tikhonenko TA and Mendell JT: Widespread microRNA repression by Myc contributes to tumorigenesis. Nat Genet 40: 43-50, 2008.

168. Bueno MJ, Gómez de Cedron M, Gomez-López G, Pérez de Castro I, Di Lisio L, Montes-Moreno S, Martinez N, Guerrero M, Sanchez-Martinez R, Santos J, et al: Combinatorial effects of microRNAs to suppress the Myc oncogenic pathway. Blood 117: 6255-6266, 2011.
169. Oduor CI, Kaymaz Y, Chelimo K, Otieno JA, Ongecha JM, Moormann AM and Bailey JA: Integrative microRNA and mRNA deep-sequencing expression profiling in endemic Burkitt lymphoma. BMC Cancer 17: 761, 2017.

170. Ott G, Rosenwald A and Campo E: Understanding MYC-driven aggressive B-cell lymphomas: Pathogenesis and classification. Blood 122: 3884-3891, 2013

171. Robaina MC, Mazzoccoli L, Arruda VO, de Souza Reis FR, Apa AG, de Rezende LMM and Klumb CE: Deregulation of DNMT1, DNMT3B and miR-29s in Burkitt lymphoma suggests novel contribution for disease pathogenesis. Exp Molec Pathol 98: 200-207, 2015.

172. Li JG, Ding Y, Huang YM, Chen WL, Pan LL, Li Y, Chen XL, Chen Y, Wang SY and Wu XN: FAMLF is a target of miR-181b in Burkitt lymphoma. Braz J Med Biol Res 50: e5661, 2017.

173. Doose G, Haake A, Bernhart SH, Lopez C, Duggimpudi S, Wojciech F, Bergmann AK, Borkhardt A, Burkhardt B, Claviez A, et al: MINCR is a MYC-induced lncRNA able to modulate MYC's transcriptional network in Burkitt lymphoma cells. Proc Natl Acad Sci USA 112: E5261-5270, 2015.

174. Watkins AJ, Hamoudi RA, Zeng N, Yan O, Huang Y, Liu H, Zhang J, Braggio E, Fonseca R, de Level L, et al: An integrated genomic and expression analysis of $7 \mathrm{q}$ deletion in splenic marginal zone lymphoma. PLoS One 7: e44997, 2012.

175. Thorns C, Kuba J, Bernard V, Senft A, Szymczak S, Feller AC and Bernd HW: Deregulation of a distinct set of microRNAs is associated with transformation of gastritis into MALT lymphoma. Virchows Arch 460: 371-377, 2012.

176. Fernández C, Bellosillo B, Ferraro M, Seoane A, SánchezGonzález B, Pairet S, Pons A, Barranco L, Vela MC, Gimeno E, et al: MicroRNAs 142-3p, miR-155 and miR-203 are deregulated in gastric MALT lymphomas compared to chronic gastritis. Cancer Genomics Proteomics 14: 75-82, 2017.

177. Liu TY, Chen SU, Kuo SH, Cheng AL and Lin CW: E2A-positive gastric MALT lymphoma has weaker plasmacytoid infiltrates and stronger expression of the memory B-cell-associated miR-223: Possible correlation with stage and treatment response. Modern Pathol 23: 1507-1517, 2010.

178. McKay P, Fielding P, Gallop-Evans E, Hall GW, Lambert J, Leach M, Marafioti T and McNamara C: Guidelines for the investigation and management of nodular lymphocyte predominant Hodgkin lymphoma. Br J Haematol 172: 32-43, 2016.

179. Swerdlow SH, Campo E, Harris NL, Jaffe ES, Pileri SA, Stein H and Thiele J: WHO classification of tumours of haematopoietic and lymphoid tissues. World Health Organization, International Agency for Research on Cancer (Revised 4th edition), 2018.

180. Re D, Roman TK, Behringer K and Diehl V: From Hodgkin disease to Hodgkin lymphoma: Biologic insights and therapeutic potential. Blood 105: 4553-4560, 2005.

181. Tan LP, Seinen E, Duns G, de Jong D, Sibon OC, Poppema S, Kroesen BJ, Kok K and van den Berg A: A high throughput experimental approach to identify miRNA targets in human cells. Nucleic Acids Res 37: e137, 2009.

182. Navarro A, Diaz T, Martinez A, Gaya A, Pons A, Gel B, Codony C, Ferrer G, Martinez C, Montserrat E and Monzo M: Regulation of JAK2 by miR-135a: Prognostic impact in classic Hodgkin lymphoma. Blood 114: 2945-2951, 2009.

183. Nie K, Gomez M, Landgraf P, Garcia JF, Liu Y, Tan LH, Chadburn A, Tuschl T, Knowles DM and Tam W: MicroRNA mediated down-regulation of PRDM1/Blimp-1 in Hodgkin/Reed-Sternberg cells: A potential pathogenetic lesion in Hodgkin lymphomas. Am J Pathol 173: 242-252, 2008.

184. Leucci E, Zriwil A, Gregersen LH, Jensen KT, Obad S, Bellan C, Leoncini L, Kauppinen S and Lund AH: Inhibition of miR-9 de-represses HuR and DICER1 and impairs Hodgkin lymphoma tumour outgrowth in vivo. Oncogene 31: 5081-5089, 2012.

185. van den Berg A, Kroesen BJ, Kooistra K, de Jong D, Briggs J, Blokzijl T, Jacobs S, Kluiver J, Diepstra A, Maggio E and Poppema S: High expression of B-cell receptor inducible gene BIC in all subtypes of Hodgkin lymphoma. Genes Chromosomes Cancer 37: 20-28, 2003.

186. Metzler M, Wilda M, Busch K, Viehmann S and Borkhardt A: High expression of precursor microRNA-155/BIC RNA in children with Burkitt lymphoma. Genes Chromosomes Cancer 39: $167-169,2004$

187. Gibcus JH, Tan LP, Harms G, Schakel RN, de Jong D, Blokzijl T, Möller P, Poppema S, Kroesen BJ and van den Berg A: Hodgkin lymphoma cell lines are characterized by a specific miRNA expression profile. Neoplasia 11: 167-176, 2009. 
188. Navarro A, Gaya A, Martinez A, Urbano-Ispizua A, Pons A, Balagué O, Gel B, Abrisqueta P, Lopez-Guillermo A, Artells R, et al: MicroRNA expression profiling in classic Hodgkin lymphoma. Blood 111: 2825-2832, 2008.

189. Sanchez-Espiridion B, Martin-Moreno AM, Montalban C, Figueroa V, Vega F, Younes A, Medeiros LJ, Alvés FJ, Canales M, Estévez M, et al: MicroRNA signatures and treatment response in patients with advanced classical Hodgkin lymphoma. Br J Haematol 162: 336-347, 2013

190. Ben Dhiab M, Ziadi S, Louhichi T, Ben Gacem R, Ksiaa F and Trimeche M: Investigation of miR9-1, miR9-2 and miR9-3 methylation in Hodgkin lymphoma. Pathobiology 82: 195-202, 2015.

191. Cao Z, Qiu J, Yang G, Liu Y, Luo W, You L, Zheng L and Zhang T: MiR-135a biogenesis and regulation in malignancy: A new hope for cancer research and therapy. Cancer Biol Med 17: 569-582, 2020

192. Solé C, Arnaiz E and Lawrie CH: MicroRNAs as biomarkers of B-cell lymphoma. Biomark Insights: Oct 162018 (Epub ahead of print). doi: $10.1177 / 1177271918806840$.

193. The Leukemia and Lymphoma Society: Non Hodgkin Lymphoma, 2006

194. Vose JM: Peripheral T-cell non-Hodgkin's lymphoma. Hematol Oncol Clin North Am 22: 997-1005, 2008.

195. Mei M and Zhang M: Non-coding RNAs in Natural Killer/T-cell lymphoma. Front Oncol 9: 515, 2019.

196. Ralfkiaer U, Hagedorn PH, Bangsgaard N, Løvendorf MB, Ahler CB, Svensson L, Kopp KL, Vennegaard MT, Lauenborg B, Zibert JR, et al: Diagnostic microRNA profiling in cutaneous T-cell lymphoma (CTCL). Blood 118: 5891-5900, 2011

197. Yamanaka Y, Tagawa H, Takahashi N, Watanabe A, Guo YM, Iwamoto K, Yamashita Y, Saitoh H, Kameoka Y and Shimizu N: Aberrant overexpression of microRNAs activate AKT signaling via downregulation of tumor suppressors in natural killer-cell lymphoma/leukemia. Blood 114: 3265-3275, 2009.

198. Zhang X, Ji W, Huang R, Li L, Wang X, Li L, Fu X, Sun Z, Li Z, Chen $\mathrm{Q}$ and Zhang M: MicroRNA-155 is a potential molecular marker of natural killer/T-cell lymphoma. Oncotarget 7 53808-53819, 2016

199. Motsch N, Alles J, Imig J, Zhu J, Barth S, Reineke T, Tinguely M, Cogliatti S, Dueck A, Meister G, et al: MicroRNA profiling of Epstein-Barr virus-associated NK/T-cell lymphomas by deep sequencing. PLoS One 7: e42193, 2012.

200. Chen HH, Huang WT, Yang LW and Lin CW: The PTEN-AKT-mTOR/RICTOR pathway in nasal natural killer cell lymphoma is activated by miR-494-3p via PTEN but inhibited by miR-142-3p via RICTOR. Am J Pathol 185: 1487-1499, 2015.

201. Liang L, Nong L, Zhang S, Zhao J, Ti H, Dong Y, Zhang B and $\mathrm{Li} \mathrm{T}$ : The downregulation of PRDM1/Blimp-1 is associated with aberrant expression of miR-223 in extranodal NK/T-cell lymphoma, nasal type. J Exp Clin Cancer Res 33: 7, 2014.

202.Huang WT and Lin CW: EBV-encoded miR-BART20-5p and miR-BART8 inhibit the IFN- $\gamma$-STAT1 pathway associated with disease progression in nasal NK-cell lymphoma. Am J Pathol 184: 1185-1197, 2014

203. Alles J, Menegatti J, Motsch N, Hart M, Eichner N, Reinhardt R, Meister G and Grasser FA: miRNA expression profiling of Epstein-Barr virus-associated NKTL cell lines by Illumina deep sequencing. FEBS Open Bio 6: 251-263, 2016.

204.Ramakrishnan R, Donahue H, Garcia D, Tan J, Shimizu N Rice AP and Ling PD: Epstein-Barr virus BART9 miRNA modulates LMP1 levels and affects growth rate of nasal NK T cell lymphomas. PLoS One 6: e27271, 2011.

205. Raab MS, Podar K, Breitkreutz I, Richardson PG and Anderson KC: Multiple myeloma. Lancet 374: 324-339, 2009.

206.Zhou Y, Zhong Y, Wang Y, Zhang X, Batista DL, Gejman R, Ansell PJ, Zhao J, Weng C and Klibanski A: Activation of p53 by MEG3 non-coding RNA. J Biol Chem 282: 24731-24742, 2007.

207. Benetatos L, Dasoula A, Hatzimichael E, Georgiou I, Syrrou M and Bourantas KL: Promoter hypermethylation of the MEG3 (DLK1/MEG3) imprinted gene in multiple myeloma. Clin Lymphoma Myeloma 8: 171-175, 2008.

208.Zhuang W, Ge X, Yang S, Huang M, Zhuang W, Chen P, Zhang X, Fu J, Qu J and Li B: Upregulation of lncRNA MEG3 promotes osteogenic differentiation of mesenchymal stem cells from multiple myeloma patients by targeting BMP4 transcription. Stem Cells 33: 1985-1997, 2015.
209. Khalil AM, Guttman M, Huarte M, Garber M, Raj A Rivea Morales D, Thomas K, Presser A, Bernstein BE, van Oudenaarden A, et al: Many human large intergenic noncoding RNAs associate with chromatin-modifying complexes and affect gene expression. Proc Natl Acad Sci USA 106: 11667-11672, 2009.

210. Bennett CF, Baker BF, Pham N, Swayze E and Geary RS Pharmacology of antisense drugs. Annu Rev Pharmacol Toxicol 57: 81-105, 2017.

211. Koch L: Functional genomics: Screening for lncRNA function. Nat Rev Genet 18: 70, 2017.

212. Gilbert LA, Horlbeck MA, Adamson B, Villalta JE, Chen Y, Whitehead EH, Guimaraes C, Panning B, Ploegh HL, Bassik MC, et al: Genome-Scale CRISPR-mediated control of gene repression and activation. Cell 159: 647-661, 2014

213. Fire A, Xu S, Montgomery MK, Kostas SA, Driver SE and Mello CC: Potent and specific genetic interference by double-stranded RNA in caenorhabditis elegans. Nature 391: 806-811, 1998

214. Elbashir SM, Harborth J, Lendeckel W, Yalcin A, Weber K and Tuschl T: Duplexes of 21-nucleotide RNAs mediate RNA interference in cultured mammalian cells. Nature 411: 494-498, 2001.

215. Brummelkamp TR, Bernards R and Agami R: A system for stable expression of short interfering RNAs in mammalian cells. Science 296: 550-553, 2002

216. Mattheolabakis G, Rigas B and Constantinides PP: Nanodelivery strategies in cancer chemotherapy: Biological rationale and pharmaceutical perspectives. Nanomedicine (Lond) 7: 1577-1590, 2012.

217. Webster DM, Sundaram P and Byrne ME: Injectable nanomaterials for drug delivery: Carriers, targeting moieties, and therapeutics. Eur J Pharm Biopharm 84: 1-20, 2013.

218. Fabbro C, Ali-Boucetta H, Da Ros T, Kostarelos K, Bianco A and Prato M: Targeting carbon nanotubes against cancer. Chem Commun (Camb) 48: 3911-3926, 2012.

219. Libutti SK, Paciotti GF, Byrnes AA, Alexander HR Jr, Gannon WE, Walker M, Seidel GD, Yuldasheva N and Tamarkin L: Phase I and pharmacokinetic studies of CYT-6091, a novel PEGylated colloidal gold-rhTNF nanomedicine. Clin Cancer Res 16: 6139-6149, 2010.

220. Yang T, Choi MK, Cui FD, Lee SJ, Chung SJ, Shim CK and Kim DD: Antitumor effect of paclitaxel-loaded PEGylated immunoliposomes against human breast cancer cells. Pharm Res 24: 2402-2411, 2007.

221. Markman JL, Rekechenetskiy A, Holler E and Ljubimova JY. Nanomedicine therapeutic approaches to overcome cancer drug resistance. Adv Drug Deliv Rev 65: 1866-1879, 2013

222. Bartolomé-Izquierdo N, de Yébenes VG, Álvarez-Prado AF, Mur SM, Lopez Del Olmo JA, Roa S, Vazquez J and Ramiro AR: miR-28 regulates the germinal center reaction and blocks tumor growth in preclinical models of non-Hodgkin lymphoma. Blood 129: 2408-2419, 2017.

223. Zhang Y, Roccaro AM, Rombaoa C, Flores L, Obad S, Fernandes SM, Sacco A, Liu Y, Ngo H, Quang P, et al: LNA-mediated anti-miR-155 silencing in low-grade B-cell lymphomas. Blood 120: 1678-1686, 2012 .

224. Seto AG, Beatty X, Lynch JM, Hermreck M, Tetzlaff M, Duvic M and Jackson AL: Cobomarsen, an oligonucleotide inhibitor of miR-155, co-ordinately regulates multiple survival pathways to reduce cellular proliferation and survival in cutaneous T-cell lymphoma. Br J Haematol 183: 428-444, 2018.

225. Li J, Zou J, Wan X, Sun C, Peng F, Chu Z and Hu Y: The role of noncoding RNAs in B-cell lymphoma. Front Oncol 10: 577890, 2020.

226. Zhang X, Xie K, Zhou H, Wu Y, Li C, Liu Y, Liu Z, Xu Q, Liu S, Xiao D and Tao Y: Role of non-coding RNAs and RNA modifiers in cancer therapy resistance. Mol Cancer 19: 47, 2020.

227. Lin R, Sampson JH, Li QJ and Zhu B: miR-23a blockade enhances adoptive $\mathrm{T}$ cell transfer therapy by preserving immune-competence in the tumor microenvironment. Oncoimmunology 4: e990803, 2015.

This work is licensed under a Creative Commons Attribution-NonCommercial-NoDerivatives 4.0 International (CC BY-NC-ND 4.0) License. 